\title{
Early Evidence on the Use of Foreign Cash Following the Tax Cuts and Jobs Act of 2017
}

\author{
Brooke Beyer \\ College of Business Administration \\ Kansas State University \\ bbeyer@ksu.edu \\ Jimmy F. Downes* \\ College of Business \\ University of Nebraska-Lincoln \\ downes@unl.edu \\ Mollie E. Mathis \\ Harbert College of Business \\ Auburn University \\ mollie.mathis@auburn.edu \\ Eric T. Rapley \\ College of Business \\ Colorado State University \\ eric.rapley@colostate.edu
}

November 2019

${ }^{*}$ Corresponding author: 445 H College of Business, P.O. Box 880488, Lincoln, NE 68588-0488;

+1 (402) 472-5152; downes@unl.edu.

Acknowledgments: We are grateful for helpful comments and suggestions from TJ Atwood, James Brushwood, Michelle Draeger, Robert Gutsche, Amy Hageman, Kim Key, Sandeep Nabar, Tom Omer, Bill Schwartz, Terry Shevlin, Jim Stekelberg, and Wayne Thomas. We appreciate the feedback from workshop participants at Auburn University, Colorado State University, Oklahoma State University, and the 2019 AAA Annual Meeting. We would also like to thank a manager in the national office of a Big 4 accounting firm for their helpful consultation as well as Madison May for her research assistance. 


\title{
Early Evidence on the Use of Foreign Cash Following the Tax Cuts and Jobs Act of 2017
}

\begin{abstract}
The Tax Cuts and Jobs Act of 2017 (TCJA) reduces multinational firms' internal capital market frictions through a deemed repatriation of unremitted foreign earnings and eliminating future repatriation tax costs. This change to the U.S. corporate tax system permanently reduces repatriation costs and gives multinational firms access to lower cost internal capital (i.e., foreign cash). This study provides evidence that multinational firms with greater levels of pre-TCJA foreign cash increased their post-TCJA repurchases but did not change their shareholder dividends or capital expenditures, on average. We further document that the increase in repurchases is driven by those firms that had greater pre-TCJA repatriation tax costs and costlier access to external finance (i.e., marginally weak financial health firms). While we do not find a relationship in the sample-wide analysis, we do find a positive relation between foreign cash and post-TCJA capital expenditures for firms that are in marginally weak financial health. Furthermore, the increase in total capital expenditures is primarily due to an increase in domestic capital expenditures rather than foreign capital expenditures. This outcome is consistent with internal capital market theory and suggests a decrease in internal capital market frictions allows companies access to trapped foreign cash.
\end{abstract}

Keywords: Tax Cuts and Jobs Act; payout policy; capital investment; internal capital market

JEL Classifications: F23, G31, G38, H25, M40, M48.

Data Availability: Data are available from the public sources cited in the text. 


\section{Early Evidence on the Use of Foreign Cash Following the Tax Cuts and Jobs Act of 2017}

\section{INTRODUCTION}

The Tax Cuts and Jobs Act of 2017 (TCJA) dramatically changed the United States (U.S.) corporate tax landscape. Before the TCJA, if U.S. multinational firms repatriated earnings from a foreign subsidiary to the U.S. parent, they were required to pay taxes on the difference between the U.S. statutory tax rate and the effective foreign tax rate when the U.S. tax rate was higher. The repatriation tax created internal capital market frictions between foreign subsidiaries and the U.S. parent (De Simone and Lester 2018); many firms indefinitely deferred payment of repatriation taxes and consequently held large amounts of cash overseas (Foley, Hartzell, Titman, and Twite 2007). Among several sweeping provisions, the TCJA required a deemed repatriation of unremitted foreign earnings (UFE) and eliminated future federal repatriation tax costs for U.S. multinational firms. ${ }^{1}$ The intent of this change is to decrease internal capital market frictions and allow foreign cash to be more easily repatriated to the domestic parent (Garber 2017). ${ }^{2}$ This study examines whether a decrease in repatriation costs created by the TCJA effects multinational firms' spending and investment of foreign cash.

The recent passing of the TCJA provides a salient setting to investigate the effect of internal capital market inefficiencies on firm investment. The literature provides evidence that repatriation costs lead to an increase in cash held by foreign subsidiaries (Foley et al. 2007), resulting in a higher likelihood of managers using foreign cash for value-destroying foreign investments (Hanlon, Lester, and Verdi 2015; Edwards, Kravet, and Wilson 2016), less efficient

\footnotetext{
${ }^{1}$ See Section 2 for additional details.

${ }^{2}$ Foreign cash is related to, but not equivalent to permanently reinvested earnings (PRE) or unremitted foreign earnings (UFE). Laplante and Nesbit (2017) discuss the differences between foreign cash, PRE and UFE; Blaylock, Downes, Mathis, and White (2019) document the high correlation (>90\%) between PRE and estimated UFE. We choose to examine foreign cash because it is often held overseas for tax reasons (Foley et al., 2007) and it is the most liquid asset that is likely to be used for investment purposes in the post-TCJA setting. Foreign cash disclosures are also the most reliable, publicly available estimates of firms' foreign cash balances.
} 
investment (Amberger, Markle, and Samuel 2018), fewer shareholder payouts and higher levels of abnormal debt (Beyer, Downes, and Rapley 2017; Nessa 2017; De Simone and Lester 2018). Based on internal capital market theory, we expect an increase in financially constrained firms' domestic capital expenditures following a decrease in internal capital market frictions (i.e., a decrease in repatriation costs [Myers and Majluf, 1984]) if these firms have domestic investment opportunities.

Opponents of the TCJA argue that the repatriated earnings would have a significant effect on shareholder payouts, but not domestic investment (Bloomberg 2017). For example, economist Kyle Pomerleau stated: "A company could get an extra couple of billion from overseas, but that doesn't change their willingness to invest the cash. Most analysts, myself included, assumed that repatriation would provide no boost in investments" (Davis and Chandra 2018). Relatedly, S\&P 500 dividends and stock repurchases were the highest they have ever been during the fourth quarter of 2018; these firms' shareholder payouts totaled a record-high \$1.26 trillion during 2018 (PR Newswire 2019). De Simone and Lester (2018) provide evidence that firms with tax-induced foreign cash may substitute debt issuance for repatriation, indicating that U.S. firms with taxinduced foreign cash do not forgo domestic investment opportunities if they are not financially constrained. Consistent with these expectations, prior research documents that the American Jobs Creation Act (AJCA) tax holiday resulted in repatriations by firms with limited investment opportunities, and these firms increased payouts to shareholders, but only marginally increased domestic investment (Blouin and Krull 2009; Dharmapala, Foley, and Forbes 2011). According to the AJCA tax holiday literature, if firms do not have domestic investment opportunities and/or are not financially constrained, we would not expect a change to domestic investment, and instead expect an increase in shareholder payouts following the TCJA. 
We examine our research question using the TCJA as a proxy for the permanent reduction in repatriation costs causing an exogenous shock to firms' internal capital markets. We examine the change in shareholder payouts (i.e., total payouts, dividends and repurchases) and capital expenditures following TCJA. ${ }^{3}$ The sample is comprised of 400 multinational firms for the years 2015, 2016 and 2018. The year 2017 is omitted because it includes cash spending decisions from both the pre- and post-TCJA time period. ${ }^{4}$ We document an increase in post-TCJA shareholder payout for firms with greater levels of pre-TCJA foreign cash. The increase in total shareholder payout for high foreign cash firms is driven by an increase in repurchases and not dividends. The increase in post-TCJA repurchases is strongest among firms with greater pre-TCJA repatriation costs and for firms in marginally weak pre-TCJA financial health.

We also document no incremental capital expenditure increase in the post-TCJA period, on average, for these high foreign cash firms. However, our results suggest that post-TCJA capital expenditures did increase more for firms with greater foreign cash that were in marginally weak financial health. This result is consistent with the AJCA findings documented in Faulkender and Petersen (2012). We extend this result further and document that domestic capital expenditures, and not foreign capital expenditures, drove the increase in post-TCJA investment for this set of firms. Finally, we find no evidence that multinational firms make capital expenditures in response to growth opportunities. Our findings are robust to using a difference-in-differences research design that compares post-TCJA multinational firm expenditures to domestic-only firm expenditures, alleviating the concern that our results are due to changes other than the taxation of

\footnotetext{
${ }^{3}$ The TCJA's main objective was economic growth, which may include many forms of investment (e.g., job creation, increased wages, expanding the business by acquiring other companies, engaging in more R\&D). We choose shareholder payouts and capital expenditures because compared to acquisitions, shareholder payouts and capital expenditures require less regulatory oversight and therefore can be executed in a timelier manner. Our sample period in the post-TCJA timeframe is short and therefore we may be unable to identify economic growth through incrementally more acquisitions.

4 To be included in the sample, each firm must have annual data for all three years.
} 
foreign earnings within the TCJA (i.e., statutory tax rate decrease, 100 percent bonus depreciation, or the limitation on interest deductibility).

We make three contributions to the literature. First, Clemons and Shevlin (2016) argue that policymakers only consider academic research when it is directly useful to those involved in the policymaking process, and the authors argue the most effective way for research to affect tax policy is to specifically discuss tax policy in research papers. This paper accomplishes both of those objectives. Our study highlights that initial evidence indicates that post-TCJA shareholder payout increased for firms with large amounts of pre-TCJA foreign cash (i.e., firms most impacted by a reduction in repatriation costs). Given a stated objective of tax reform was to increase economic growth (Whitehouse.gov), which can be accomplished through domestic investment, we believe our findings are particularly relevant to policymakers. Specifically, we provide evidence about investment behavior after the enactment of the TCJA.

Second, this study builds on prior literature examining the effect of reductions in internal capital market frictions on domestic investment. Using the AJCA as a setting for reduced internal capital market frictions, prior studies find no evidence that the modified world-wide tax system limited U.S. multinationals domestic investment because they do not document an increase in investment following the AJCA tax holiday (Blouin and Krull 2009; Dharmapala et al. 2011). While the AJCA was a temporary, non-mandatory tax holiday, the TCJA is mandatory, requiring a deemed repatriation with a change to a quasi-territorial system along with various other provisions aimed at increasing domestic investment. However, despite the differences in the tax policies, our results indicate that, with the exception of marginally weak financial health firms, U.S. multinationals with high pre-TCJA foreign cash did not increase capital expenditures. Prior literature that examines the change from a worldwide to territorial tax system in Japan and the 
United Kingdom documents that firms accumulate less cash, payout cash to shareholders via dividends and repurchases, and invest less abroad following the change in tax system (Arena and Kutner, 2015). Our evidence documents similar results. Taken together, our study supports TCJA critics' claims that payouts to shareholders would increase following the permanent reduction in repatriation costs.

Finally, we contribute to the literature examining the influence of taxes on firm decisionmaking. Edwards et al. (2016) and Hanlon et al. (2015) provide evidence that firms make less successful foreign acquisitions with trapped foreign cash. Additionally, Blouin and Krull (2009) and Dharmapala et al. (2011) provide evidence that firms increased share repurchases in response to the AJCA tax holiday. We contribute to this literature by providing evidence that high foreign cash firms increased shareholder repurchases and not capital expenditures in response to the TCJA, indicating that the U.S. worldwide tax system influenced firm decisionmaking.

The next section describes the Tax Cuts and Jobs Act of 2017. Section 3 reviews the relevant literature and develops hypotheses. Section 4 presents the research methodology and sample selection. Section 5 discusses the empirical results, and Section 6 concludes the paper.

\section{THE TAX CUTS AND JOBS ACT OF 2017}

President Trump and a Republican-controlled Congress turned their attention to tax reform in the late stages of summer 2017. The House Ways and Means Committee released a draft bill on November $2^{\text {nd }}$ and approved it on November $9^{\text {th }}$. On November $16^{\text {th }}$, the House floor passed a revised version and the Senate Finance Committee approved a version of the tax reform bill. The Senate passed a revised bill on December $2^{\text {nd }}$. The final TCJA was passed in the House of 
Representatives and Senate on December $19^{\text {th }}$ and December $20^{\text {th }}$, respectively. President Trump then signed the TCJA into law on December 22, 2017.

Major corporate tax changes under the TCJA fall into four categories: statutory tax rate decrease, 100 percent bonus depreciation, interest deductibility, and foreign earnings taxation. First, the TCJA reduces the corporate statutory tax rate from a maximum rate of 35 to a flat rate of 21 percent. Second, the TCJA allows firms to deduct 100 percent of qualified capital expenditures as bonus depreciation and increases IRC Sec. 179 expensing to $\$ 1,000,000$. Previously, firms could deduct 50 percent of capital expenditures as bonus depreciation with the ability to expense an additional $\$ 510,000$ in qualifying IRC Sec. 179 depreciation. Third, the TCJA limits the deductibility of business interest expense to business interest income plus 30 percent of adjusted taxable income. ${ }^{5}$ Fourth, the TCJA moves the U.S. from a modified worldwide tax system to a quasi-territorial tax system.

To transition the U.S. to a quasi-territorial tax system, the TCJA required a deemed repatriation of unremitted foreign earnings from specified foreign corporations (SFCs). ${ }^{6}$ The deemed repatriation is subject to a dividends received deduction that effectively reduces the tax rate to 15.5 percent for foreign cash and 8 percent for other assets with the ability to utilize foreign tax credits (FTCs) to reduce this tax liability, which is payable over eight years (Nevius 2017). Under the new, quasi-territorial tax system, SFCs receive a 100 percent dividends received deduction for foreign earnings, effectively eliminating U.S. federal repatriation taxes on

\footnotetext{
${ }^{5}$ Internal Revenue Code (IRC) Sec. 163(j) defines the limitation on interest deductibility. Adjusted taxable income is computed without allowable deductions for amortization, depreciation, depletion, or business interest expense. Additionally, firms whose average gross receipts do not exceed \$25 million for the three prior years are exempt from the business interest expense limitation.

${ }^{6} \mathrm{SFCs}$ are controlled foreign corporations with a domestic corporation shareholder owning 10 percent or more of the stock for its last tax year prior to January 1, 2018. U.S. multinational companies include as subpart F income their pro-rata share of the greater of the SFCs accumulated post-1986 deferred foreign income determined as of November 2, 2017 or December 31, 2017.
} 
those future earnings. ${ }^{7}$ All else equal, a shift to a quasi-territorial tax system could increase profit shifting as foreign source income is exempt from home country taxation. However, the TCJA contains several provisions such as the GILTI inclusion, FDII deduction, and the base erosion and anti-abuse tax (BEAT) to limit profit shifting. Additionally, the reduced U.S. corporate tax rate decreases the benefits of shifting profits abroad as the spread between the U.S. statutory rate and foreign tax rates decreases or disappears.

\section{HYPOTHESIS DEVELOPMENT}

\subsection{Internal Capital Market and Domestic Investment}

Firms with efficient internal capital markets create value by allocating resources to business segments unable to generate sufficient funding for investment opportunities (Weston 1970; Williamson 1975; Stein 1997; Billett and Mauer 2003). For example, firms can use cash flow from one business segment or division to fund a capital project in another business segment or division. Efficient internal capital markets allow financially constrained business segments to access lower cost internal capital to fund positive net present value projects.

The literature documents several frictions that create inefficient internal capital markets: internal agency costs, external agency costs, and repatriation costs. First, Desai, Foley, and Hines (2007) suggest that when internal agency problems between parent company managers and foreign operations managers increase, firms are more likely to repatriate cash held in foreign subsidiaries to avoid foreign operations managers' self-maximizing behavior. For firms with centralized treasury functions, internal agency costs are less of a concern. However, external

\footnotetext{
${ }^{7}$ U.S. multinational firms could still have state repatriation taxes and foreign withholding taxes on remitted earnings. As a result, some firms have significantly reduced rather than eliminated internal capital market frictions with regards to repatriated funds.
} 
agency costs, arising from the agency conflict between parent company managers and shareholders, may also increase the likelihood of misallocation of internal resources. The literature suggests external agency costs could encourage managers to extract private benefits of control by investing in suboptimal growth opportunities (Jensen 1986; Hope and Thomas 2008), make value-destroying capital expenditures (Shin and Stulz 1998) and acquisitions (Hanlon et al. 2015; Edwards et al. 2016), and acquiesce to rent-seeking behavior by subsidiary managers (Datta, D’Mello, and Iskandar-Datta 2009).

Finally, repatriation costs may limit firms' ability to allocate resources among their domestic and international business operations efficiently. Theory and prior empirical work indicate that using internal capital to fund operations within a firm is generally less costly than external capital because of information asymmetry problems (Myers 1984; Myers and Majluf 1984; Shyam-Sunders and Myers 1999). However, large multinational firms continued to issue debt to satisfy investors' demands of return of capital in the pre-TCJA era. For example, to complete repurchases and the payment of dividends, Apple borrowed $\$ 17$ billion in 2013 (Lattman and Eavis 2013), and eBay borrowed \$3 billion in 2012 (Mead and Kucera 2012). Beyer et al. (2017) provide evidence consistent with repatriation costs increasing abnormal debt to fund shareholder payouts. De Simone and Lester (2018) document that frictions created by repatriation taxes explain the use of external domestic debt financing by these cash-rich firms. Because of the increased tax and financial reporting costs associated with repatriations, research suggests a positive association between repatriation costs and cash held by foreign subsidiaries (Foley et al. 2007; Hanlon et al. 2015).

Prior literature explores the effect of the American Jobs Creation Act on firm behavior. The AJCA temporarily decreased repatriation taxes on foreign earnings, temporarily making internal 
capital less costly to access. ${ }^{8}$ On the one hand, Blouin and Krull (2009) and Dharmapala et al. (2011) provide evidence consistent with firms using repatriated earnings from the AJCA tax holiday to increase shareholder payouts instead of domestic capital investments. On the other hand, Faulkender and Petersen (2012) find that while most firms that voluntarily repatriated earnings increased shareholder payouts, financially constrained (i.e., weaker financial health) firms increased domestic investment after the AJCA. Additionally, Arena and Kutner (2015) examine the United Kingdom and Japan transitions from worldwide tax systems to territorial tax systems and find that payouts increase but document no change in domestic investment. These results confirm that reductions in internal capital market frictions only increase domestic investment when firms have financial constraints and domestic investment opportunities.

While prior research documents that reductions in repatriation taxes largely lead to increases in shareholder payouts and not capital investment, there are unique features of the TCJA that could lead to differing results. Specifically, while the AJCA was temporary and participation was optional, the deemed repatriation under the TCJA and the quasi-territorial tax system are mandatory and implement large inclusion regimes (i.e., GILTI) that are unique to the U.S. ${ }^{9}$ The permanent reduction in repatriation taxes grants companies access to additional cash on a longterm basis. As a result, companies may be more likely to make long-term capital investment decisions rather than short-term shareholders payouts via share repurchases which are generally made as a result of temporary cash inflows (Allen and Michaely, 2003; Brav, Graham, Harvey,

\footnotetext{
${ }^{8}$ Similar to the TCJA, the AJCA provided a dividends received deduction for repatriating firms. However, the AJCA provided an 85 percent dividends received deduction when the statutory tax rate was 35 percent, resulting in an effective 5.25 percent tax rate on repatriated earnings minus any available foreign tax credits. The dividends received deduction was offered on the greater of $\$ 500$ million or earnings designated as permanently reinvested in the financial statements issued on or before June 20, 2003. Additionally, repatriation under the AJCA was optional. ${ }^{9}$ For example, the TCJA introduces a global intangible low-taxed income (GILTI) inclusion to discourage income shifting from the U.S. to foreign jurisdictions and among foreign jurisdictions. Importantly, GILTI proxy for intangible income using a return on foreign tangible assets. Thus, to minimize overall taxes, firms can minimize their GILTI inclusion by increasing foreign investment in tangible assets.
} 
and Michaely, 2005; DeAngelo, DeAngelo, and Stulz, 2006; Beyer et al., 2017). Further, in contrast to prior findings related to the United Kingdom and Japan transitions to a territorial tax system (Arena and Kutner, 2015), the United States has greater opportunities for companies to invest capital. ${ }^{10}$ Additionally, Hanlon, Hoopes, and Slemrod (2018) analyze earnings conference calls and find a number of firms stating they would increase investment post-TCJA. Further, their study finds that firms with greater expected tax savings from the TCJA are more likely to announce investment plans. Therefore, because repatriation taxes increase the cost of accessing internal capital, the new U.S. tax policy significantly reduces repatriation taxes, and firms are communicating plans to increase investment, U.S. multinational firms could increase capital expenditures post-TCJA.

Due to the significant differences between the TCJA and the AJCA and the findings from Hanlon et al. (2018), we examine the relation between firms' foreign cash levels pre-TCJA and shareholder payouts and capital expenditures post-TCJA. ${ }^{11}$ The enactment of the TCJA created a permanent reduction in repatriation taxes decreasing internal capital market frictions, and, in turn, providing companies access to lower cost internal capital to spend on domestic capital investments. Prior literature suggests the AJCA, a temporary tax holiday, increased shareholder payout but did not increase capital expenditures (Blouin and Krull. 2009; Dharmapala et al., 2011). However, there are reasons to believe the different tax provisions included in the TCJA may lead to companies making different decisions about how they spend their excess foreign cash. Therefore, our hypotheses are stated in the null form:

\footnotetext{
${ }^{10}$ According to World Population Review (GDP Ranked by Country 2019), which ranks the Gross Domestic Product (GDP) by country, the United States has by far the highest GDP ( $\$ 21.41$ trillion) compared to Japan ( $3^{\text {rd }}$, $\$ 5.36$ trillion) and the United Kingdom ( $7^{\text {th }}, \$ 3.02$ trillion).

${ }^{11} \mathrm{We}$ recognize that firms have incentives and/or lack of consequences that can prompt managers to make claims that do not necessarily match their true intentions. For instance, Graham, Hanlon, and Shevlin (2010)'s survey reports U.S. capital investment as the most prominent use of repatriated cash from the AJCA. However, Blouin and Krull (2009) and Dharmapala, Foley, and Forbes (2011) results do not support these claims.
} 
Hypothesis 1a. Firms with higher levels of foreign cash pre-TCJA, compared to firms with lower levels of foreign cash, do not increase shareholder payouts post-TCJA.

Hypothesis 1b. Firms with higher levels of foreign cash pre-TCJA, compared to firms with lower levels of foreign cash, do not increase capital expenditures post-TCJA.

In addition to the effects of reduced internal capital market frictions on domestic investment, other provisions of the TCJA may also impact domestic investment. Specifically, the corporate tax rate reduction should decrease the cost of capital, increasing the number of domestic, positive net present value projects. However, while bonus depreciation may increase incentives for capital expenditures, it may also dampen the impact of the corporate tax rate reduction on firm investment (Slemrod 2018). The effects of these two provisions should not be more pronounced among firms with high foreign cash unless repatriation costs under the old tax regime were a source of internal capital market frictions. We will examine these potential influences by comparing multinational firms to a sample of firms that only have domestic operations to eliminate these alternative explanations.

\section{RESEARCH DESIGN AND DATA}

\subsection{Research Design}

To analyze the TCJA's effect on corporate spending and investment, we first examine preTCJA versus post-TCJA and focus on the incremental effect of pre-TCJA foreign cash on multinational firms' post-TCJA expenditure. Our model examines expenditure (i.e., dividends, repurchases and capital expenditures) as a function of foreign cash and other firm characteristics.

$$
\begin{aligned}
& \text { Expenditure }_{i, t}=\alpha_{0}+\alpha_{1} \text { Post }_{t}+\alpha_{2} \text { Foreign Cash }_{i}+\alpha_{3} \text { Foreign Cash }_{i} \times \text { Post }_{t}+\alpha_{4} \text { Domestic } \\
& \text { Cash }_{i}+\alpha_{5} \text { Book ETR }_{i}+\alpha_{6} \text { Cash ETR }_{i}+\alpha_{7} \text { Loss }_{i, t}+\alpha_{8} \text { Size }_{i}+ \\
& \alpha_{9} \text { Earnings }_{i, t}+\alpha_{10} \text { Cash Flow }_{i, t}+\alpha_{11} \text { Leverage }_{i, t}+\alpha_{12} M T B_{i, t}+ \\
& \alpha_{13} \text { Sales Growth } h_{i, t}+\alpha_{14} \text { CapEx2014 }{ }_{i}+\alpha_{15} R D_{i, t}+\alpha_{16} A C Q_{i, t}+\alpha_{17} \text { Firm } \\
& A g e_{i, t}+\alpha_{18} R E / B V_{i, t}+\alpha_{19} \text { Returns }_{i, t}+\alpha_{20} \text { Options }_{i, t}+\alpha_{21} \text { St. Dev. } \\
& \text { Earnings }_{i, t}+\alpha_{22} \text { Dividends }_{i, t-1}+\alpha_{23}{\text { Repurchases } s_{i, t-1}+\varepsilon}
\end{aligned}
$$


Equation (1) is estimated separately for each of the following dependent variable measures for Expenditure: Total Payout, Dividends, Repurchases, and CapEx. Total Payout is equal to the sum of cash distributions from dividends and share repurchases, all scaled by end of fiscal year 2014 total assets. ${ }^{12}$ Dividends is defined as total dividends scaled by end of fiscal year 2014 total assets. Repurchases is equal to the purchase of common and preferred stock less any decrease in the redemption of preferred stock or less any decrease in preferred stock if the redemption value of preferred stock is missing, all scaled by end of fiscal year 2014 total assets. When examining payout levels, a Tobit regression is used to estimate Equation (1) given that many firms do not distribute cash to shareholders resulting in a dependent variable equal to zero. CapEx is capital expenditures scaled by end of fiscal year 2014 total assets. Foreign Cash is foreign cash balance at the end of fiscal year 2014 (hand-collected from 10-Ks) scaled by total assets at the end of fiscal year 2014. Domestic Cash is total cash minus foreign cash scaled by total assets, all measured at the end of fiscal year 2014. Post is equal to one for fiscal years ending in 2018 and zero for fiscal years ending prior to 2018. Foreign cash is not equivalent to permanently reinvested earnings (PRE) or unremitted foreign earnings (UFE). Laplante and Nesbit (2017) discuss the differences between foreign cash, PRE and UFE; Blaylock et al. (2019) document the high correlation (>90\%) between PRE and estimated UFE. We examine foreign cash because it is often held overseas for tax reasons (Foley et al., 2007) and it is the most liquid asset that is likely to be used first for investment purposes in the post-TCJA setting. A positive and significant estimated coefficient on the interaction Foreign Cash $\times \operatorname{POST}\left(\alpha_{3}\right)$ rejects Hypothesis $1 \mathrm{a}$ and $1 \mathrm{~b}$.

\footnotetext{
${ }^{12}$ Fiscal year 2014 total assets is used as the common scalar (instead of lagged total assets) so that prior period's expenditure does not affect the current period's denominator in the variable calculation.
} 
Control variables are based on other tax changes included in the TCJA and prior literature that examines payout policy (Fama and French, 2001; DeAngelo et al., 2006; Grullon, Paye, Underwood, and Weston, 2011) and capital investment (Canace, Jackson, and Ma, 2018). The TCJA lowered the overall U.S. corporate tax rate from a maximum of $35 \%$ to $21 \%$. Such a lowering of the corporate rate would also benefit profitable firms with significant foreign cash. Therefore, we control for pre-TCJA effective tax rates. Book ETR is equal to fiscal year-end 2014 income tax expense scaled by pretax income minus special items, truncated at zero and one. Cash ETR is equal to fiscal year-end 2014 cash taxes paid scaled by pretax income minus special items, truncated at zero and one. We expect more profitable firms and firms with higher effective tax rates to benefit more from a reduction of the corporate tax rate. Therefore, we also control for loss firms by including Loss, set equal to one when income before extraordinary items is less than zero and equal to zero otherwise.

Size is equal to the natural logarithm of fiscal year 2014 total assets. Earnings is income before extraordinary items scaled by fiscal year 2014 total assets. Cash Flow is operating cash flows scaled by fiscal year 2014 total assets. Leverage is long term debt scaled by fiscal year 2014 total assets. MTB is the market value of equity scaled by book value of equity. Sales Growth is current period sales minus prior period sales, all scaled by prior period sales. CapEx2014 is total capital expenditures scaled by total assets, all measured in fiscal year 2014. $R D$ is total research and development expense scaled by fiscal year 2014 total assets. $A C Q$ is funds spend on mergers and acquisitions scaled by fiscal year 2014 total assets. ${ }^{13}$ Firm Age is equal to the natural logarithm of the number of years that the firm has appeared in the Compustat database. $R E / B V$ is retained earnings scaled by book value of equity.

${ }^{13} R D$ and $A C Q$ are set equal to zero when missing in Compustat. 
We also include controls for past stock returns (Returns), stock options (Options), and volatility of earnings (St. Dev. Earnings). Returns is measured as the firm's stock return compounded monthly for the two-year period ending before the current year. Options is calculated as the annual percentage change in total diluted shares outstanding as if no repurchases occurred the current year. St. Dev. Earnings is measured as the standard deviation of earnings for the current and previous four years. We also include lagged values of shareholder payouts (Dividends and Repurchases) because they can be sticky from the previous year. All continuous variables are winsorized at the $1^{\text {st }}$ and $99^{\text {th }}$ percentiles to lessen the influence of outliers and data errors.

\subsection{Sample Selection}

The TCJA became law on December 22, 2017. Due to limited availability of post-TCJA data for non-December fiscal year-ends, the sample is limited to firms with a calendar fiscal year-end and includes fiscal years 2015, 2016 and 2018. We exclude fiscal years ending on December 31, 2017 because they include both pre- and post-TCJA activity. Our analysis compares two years pre-TCJA to one year post-TCJA, however, inferences remain the same when we compare one year pre-TCJA (2016) to one year post-TCJA (2018). We choose to use an unbalanced sample to alleviate the concern that firms invested less in 2016 due to economic uncertainty and were postponing investment until after potential tax reform becomes effective. We include firms in the sample when they have all variables available in 2015, 2016 and 2018, and disclose foreign cash in fiscal year 2014. About 64 percent of multinational firms disclose foreign cash in fiscal year 2014. ${ }^{14}$ The analysis utilizes 1,200 annual observations for 400 multinational firms with data available on Standard and Poor's Compustat.

\footnotetext{
${ }^{14}$ Our inferences are subject to the caveat that they only apply to firms that disclose foreign cash. However, firms that disclose foreign cash are large firms that have greater amounts of total cash and are the most profitable
} 


\subsection{Descriptive Statistics and Correlations}

Table 1 reports the summary statistics for the variables used in the study. The mean (median) Total Payout is 5.7 (2.9) percent of assets which is influenced more by Repurchases rather than Dividends which have a mean (median) of 4.1 (1.4) and $1.6(0.2)$ percent of assets, respectively. The mean (median) of CapEx is 4.2 (1.7) percent of assets. By construction, the average for POST is 0.333 indicating that each firm has three years of data included (i.e., two years preTCJA and one year post-TCJA). On average, firms have 8.4 (11.7) percent of their total assets held in foreign (domestic) cash.

Table 2 reports the Pearson (Spearman) correlation coefficients below (above) the diagonal. All bold and italicized correlations are statistically significant at the 10 percent level. Consistent with expectations, the positive correlations between the measures and their lagged values indicate that shareholder payouts and capital expenditure are generally persistent from year to year. Additionally, each shareholder payout and capital expenditures have increased post-TCJA as evidenced by their positive correlation with Post.

\section{RESULTS}

\subsection{The Use of Foreign Cash Following the TCJA: Baseline Regressions}

Table 3 presents the coefficient estimates from our baseline regression specification described above in section 4.1. The sample includes two years pre-TCJA and one year postTCJA for multinational firms. The dependent variable is Total Payout, Dividends, Repurchases and CapEx across the columns. In column 1, the coefficient on Foreign Cash $\times$ Post is positive and significant $(t$-statistic $=1.95)$ suggesting that multinational firms with greater levels of pre-

(Bjornsen, Downes, and Omer, 2019) making them most likely to make economically-impactful investments following the TCJA. 
TCJA foreign cash increased their shareholders payouts in the post-TCJA time period.

Economically, a one standard deviation increase in foreign cash (0.085) leads to an incremental increase in post-TCJA payout of 19 percent. ${ }^{15}$ Average total assets of the sample are $\$ 8.02$ billion (untabulated). Therefore, a one standard deviation increase in pre-TCJA foreign cash is associated with a post-TCJA increase in total payout of $\$ 86$ million or about 1 percent of assets.

The increase in total payout is driven by an increase in repurchases and not dividends. Specifically, the coefficient on Foreign Cash $\times$ Post in column 2 is not significantly different from zero. However, the coefficient on Foreign Cash $\times$ Post in column 3 is positive and significant $(t$-statistic=1.78). Economically, a one standard deviation increase in pre-TCJA foreign cash leads to a 24 percent increase in post-TCJA repurchases. Finally, the coefficient on Foreign Cash $\times$ Post in column 4 is not significantly different from zero suggesting that multinational firms with large pre-TCJA foreign cash balances did not immediately increase their capital expenditures in the year following the TCJA compared to firms without large pre-TCJA foreign cash balances.

The significant association between foreign cash and post-TCJA share repurchases and insignificant association between foreign cash and post-TCJA dividends is consistent with previous research. Prior literature indicates that shareholders react negatively to reductions in dividends (Aharony and Swary 1980). Blouin and Krull (2009) highlight that firms typically prefer repurchases to dividends because repurchases are not "sticky" (Guay and Harford 2000; Jagannathan, Stephens, and Weisbach 2000). Additionally, Blouin and Krull (2009) argue that share repurchases generate capital gains, which allows for the deferral of taxes, a return of capital upon sale, timing of sale to match capital losses, and use of capital loss carryforwards.

${ }^{15}([0.085 \times 0.126] \div 0.057)$ 
The evidence in Table 3 rejects Hypothesis 1a but fails to reject Hypothesis 1b, suggesting that multinational firms with greater amounts of pre-TCJA foreign cash were most likely to use newly accessible foreign cash for shareholder repurchases and not dividends or capital expenditures. These results are largely consistent with the findings in Blouin and Krull (2009) who examine the consequences of the AJCA.

\subsection{Repatriation Costs}

In Table 4, we present cross-sectional analysis based on levels of repatriation costs. Firms with large amounts of foreign cash primarily accumulated those cash balances as a result of repatriation costs (Foley et al., 2007). If the TCJA drives the increase in repurchases then we expect the results from Table 3 to be the strongest for firms facing high repatriation costs because the TCJA largely eliminated repatriation costs. We limit the shareholder payout analysis to repurchases given that it drives the baseline results in Table 3. Columns 1 and 2 examine repurchases for firms facing high and low pre-TCJA repatriation costs, respectively. The coefficient on Foreign Cash $\times$ Post is positive and significant $(t$-statistic=2.50) in the subset of firms facing high (i.e., above the sample median) repatriation costs. The coefficient estimate is not significantly different from zero for the subsample of firms facing low pre-TCJA repatriation costs (column 2). The dependent variable in columns 3 and 4 is capital expenditures, and the coefficient on Foreign Cash $\times$ Post continues to be insignificant consistent with our findings in Table 3.

Overall, Table 4 documents that multinational firms with high levels of pre-TCJA foreign cash increased post-TCJA repurchases as a result of the reduction in repatriation costs. The TCJA reduced capital market frictions created by repatriation costs, which did not affect capital investment but instead increased payouts to shareholders. 


\subsection{Financial Health and Investment Opportunities}

We next examine whether the baseline results presented in Table 3 vary based on firms' financial health and investment opportunities. Before the enactment of TCJA, managers were motivated to delay repatriation of foreign cash due to repatriation taxes which discouraged managers from taking advantage of investment opportunities and also from returning cash to shareholders resulting in internal capital market inefficiencies. However, firms in strong financial health, not financially constrained, have access to external financing to fund shareholder payouts (Beyer et al., 2017) and capital investments (Albring, 2006). To the extent internal capital market frictions created by repatriation taxes limited financially constrained (i.e., weak financial health) firms from returning cash to shareholders and taking advantage of domestic investment opportunities, shareholder payouts and capital expenditures should increase post-TCJA. Therefore, we expect the reduction in internal capital market frictions to primarily change the investment behavior of firms that are in weaker financial health (i.e., firms with greater borrowing costs in the pre-TCJA period).

Table 5 examines repurchases and capital expenditures for firms in varying degrees of financial health. We partition the sample into quartiles of financial health based on the Altman (1968) Z-Score. The first, second, third and fourth quartiles are identified as weak, marginally weak, marginally strong and strong financial health firms, respectively. ${ }^{16}$ Columns $1-4(5-8)$ examine repurchases (capital expenditures). The coefficient on Foreign Cash $\times$ Post is positive and significant for firms that are in the marginally weak financial health partition both when the dependent variable is Repurchases (column 2) and CapEx (column 6). ${ }^{17}$ This suggests that weak

\footnotetext{
${ }^{16}$ We do not perform a similar quartile analysis for repatriation costs because, similar to prior literature (Foley et al., 2007; Nessa, 2017), more than half of the firms in the sample have calculated repatriation costs equal to zero.

${ }^{17}$ The sample Z-Score that corresponds to the second quartile is a Z-Score between 2.131 and 3.456 which is a little greater than how Altman (1968) defines the gray area of financial health (i.e., 1.8 - 3.0). Our sample of firms is
} 
financial health firms did not respond to the TCJA given the lack of statistical significance in columns 1 and 5. Presumably, the weakest financial health firms have low foreign cash balances because their foreign operations are not profitable or they have had a need to previously access foreign cash (and incurred the repatriation cost under the pre-TCJA regime). ${ }^{18}$ However, it appears that the TCJA reduced capital market frictions for firms that were in a marginally weak financial health state and possibly did not have low-cost access to external capital. Interestingly, the TCJA affected repurchases and capital expenditures for the same set of firms. We interpret these findings to suggest that strong financial health firms had either the resources to meet investor repurchases demand in the pre-TCJA period, or these firms were able to obtain external financing in order to meet investor repurchases demand. We also identify a setting where capital expenditures increased for firms that had greater amounts of pre-TCJA foreign cash.

Specifically, marginally weak financial health firms with greater levels of pre-TCJA foreign cash increased capital expenditures in the post-TCJA time period. This evidence is consistent with Faulkender and Petersen (2012) and documents a set of firms most affected by the elimination of U.S. repatriation taxes. Reducing internal capital market frictions does not appear to affect the relationship between foreign cash and either repurchases or capital expenditures for strong financial health firms. This is most likely due to their ability to generate cash from operations to fund their investments and/or their ability to borrow, reducing the reliance on foreign cash.

We also examine whether the spending and investment of foreign cash is affected by the firms' growth opportunities. Prior literature uses the market-to-book ratio to measure growth

made up of large multinational firms which most likely causes a shift in the distribution to more positive Z-Score values. The marginally weak financial health firms are a relative comparison to other firms in our sample.

${ }^{18}$ Consistent with this notion, the correlation between Z-Score and Foreign Cash is positive and significant at the 5 percent level (untabulated) suggesting that firms in stronger financial health (i.e., greater Z-Score) hold greater amounts of foreign cash. 
opportunities (Faulkender and Petersen, 2012; Blouin and Krull, 2009). However, we are unable to disentangle domestic and foreign growth opportunities when using the firm-level market-tobook ratio. The reduction in repatriation costs allows firms to use foreign cash to respond to domestic growth opportunities, whereas there should be little response to foreign growth opportunities. We indirectly proxy for domestic level growth opportunities by using the level of firm-level underinvestment as measured by Biddle, Hilary, and Verdi's (2009) model of investment efficiency. ${ }^{19}$ Firms that historically underinvest are identified as firms with the greatest domestic growth opportunities. We reason that underinvestment captures domestic and not foreign growth opportunities because firms would have the ability to use pre-TCJA foreign cash to reduce foreign underinvestment. The results for repurchases and capital expenditures are presented in Table 6. For repurchases (columns $1-4$ ), the coefficient on Foreign Cash $\times$ Post is positive and significant across the first three quartiles of growth opportunity measures. With the exception of the partition including high overinvestment/low growth opportunities, multinational firms used foreign cash balances to increase repurchases across all levels of growth opportunities. In columns $5-8$, the dependent variable is capital expenditures, and the coefficient on Foreign Cash $\times$ Post is not significantly different from zero in all four partitions.

Overall, the results presented in Tables 5 and 6 suggest that firms that were in a marginally weak financial position and had high levels of pre-TCJA foreign cash were most likely to increase post-TCJA repurchases and capital expenditures. Firms along the rest of the financial health continuum did not change their investment and spending behavior following the TCJA. In addition, growth opportunities do not appear to be the driving force behind the post-TCJA spending and investment decisions for multinationals' foreign cash.

\footnotetext{
${ }^{19}$ Inferences are similar if we use the market-to-book ratio to proxy for growth opportunities.
} 


\subsection{Domestic and Foreign Capital Expenditures}

The only setting where we find an increase in total capital expenditures is for those firms that are in marginally weak financial health (Table 5). Our prior discussion develops why domestic investment may increase for these firms pre-TCJA. However, it is also possible that foreign capital expenditures increase post-TCJA. First, the TCJA introduces a GILTI inclusion to discourage income shifting from the U.S. to foreign jurisdictions and among foreign jurisdictions. Due to the nature of the calculation, in order to reduce U.S. tax liability associated with GILTI, firms can minimize their GILTI inclusion by increasing foreign investment in tangible assets. Second, De Waegenaere and Sansing (2008) show that pre-TCJA, firms should underinvest in foreign operating assets, using foreign earnings to grow to the optimal size and, therefore, avoiding U.S. repatriation taxes. Because the TCJA eliminates the option to defer U.S. repatriation taxes on foreign earnings, the TCJA also eliminates the advantages of the underinvestment strategy recommended in De Waegenaere and Sansing (2008). Therefore, firms may increase foreign capital expenditures following the passage of the TCJA in order to achieve the optimal size of operations. Firms are not required to disclose disaggregated capital expenditures. However, firms are required to include the net property, plant, and equipment levels for both domestic and foreign operations in their annual segment disclosures within their 10-Ks (ASC 280-10-50-41). ${ }^{20}$ We hand-collect domestic and foreign net property, plant, and equipment for fiscal years ending during the period 2015 - 2018 for our sample. We use these hand-collected disclosures to compute changes in net domestic and foreign property, plant, and equipment from 2015 to 2016 and 2017 to 2018 . We omit the 2016 to 2017 change because the

\footnotetext{
${ }^{20}$ The Computstat Segment database does provide foreign and domestic capital expenditures, but less than 10 percent of firms in the database have data for these amounts due to inconsistent disclosure. Our approach of handcollecting domestic and foreign net property, plant, and equipment is an attempt to improve on prior literature's challenge of measuring domestic versus foreign investment described in Dong, Cao, Zhao, Deshmukh (2019).
} 
TCJA became effective in this period, and details were made public before the enactment. Therefore, our analysis compares the 2016 domestic/foreign capital expenditures with the 2018 domestic/foreign capital expenditures. We limit our sample to marginally weak financial health firms based on the findings in Table 5 .

Table 7 presents the estimated coefficients. The dependent variable in columns 1 and 2 is domestic capital expenditures and foreign capital expenditures, respectively. The coefficient on Foreign Cash $\times$ Post is positive and significant in column 1 only. This suggests that the change in repatriation costs incentivized multinational firms that were marginally constrained to increase domestic capital expenditures rather than foreign capital expenditures.

\subsection{Difference-in-differences Analysis}

Our main findings provide evidence that multinational firms with greater foreign cash levels, compared to firms with lesser foreign cash levels, increased repurchases and some firms (i.e., those in marginally weak financial health) increased domestic capital expenditures. As discussed earlier, the TCJA consisted of several broad changes (e.g., statutory tax rate decrease, 100 percent bonus depreciation, interest deductibility, and foreign earnings taxation). We argue that our findings are due to the change in the taxation of foreign earnings and not the other three broad changes. In order to provide stronger evidence for this conclusion, we use a difference-indifferences research design that compares repurchases and capital expenditures of multinational firms (i.e., treatment group) to domestic-only firms (i.e., control group). Multinational and domestic firms are similarly affected by all broad TCJA changes except the taxation of foreign earnings. The change in the taxation of foreign earnings does not affect domestic firms. We use the following difference-in-differences model:

$$
\text { Expenditure }_{i, t}=\alpha_{0}+\alpha_{1} \text { Post }_{t}+\alpha_{2} M N C_{i}+\alpha_{3} M N C_{i} \times \text { Post }_{t}+\text { Controls }+\varepsilon
$$


Expenditure takes the value of either Total Payout, Repurchases, CapEx, or Domestic CapEx, defined above. Post is defined above and $M N C$ is equal to one if the firm reports foreign income in any period 2011 - 2013. Controls includes all of the same controls from equation (1). The estimated coefficients from equation (2) are presented in Table 8 Panel A for the full sample. The coefficient on $M N C \times$ Post is positive and significant when the dependent variable is Total Payout (column 1), Repurchases (column 2), and Domestic CapEX (column 4). These findings are consistent with the main findings and provide stronger evidence that multinational firms (i.e., firms with foreign cash most affected by the change in the taxation of foreign earnings) increase repurchases and domestic capital expenditures in the post-TCJA period. Table 8 Panel B examines repurchases and domestic capital expenditures for a disaggregated sample based on financial health. We disaggregate the sample at the median Z-Score levels and include weak (strong) financial health firms in columns 1 and 3 ( 2 and 4). The dependent variable in columns 1 and 2 (3 and 4) is Repurchases (Domestic CapEX). The coefficient on MNC $\times$ Post is positive and significant in the weak financial health firms only. This confirms the evidence presented in Table 5 when the sample only includes multinational firms. Overall, using a difference-in-differences research design confirms our inferences when limiting the sample to multinational firms only, and alleviates the concern that our results are due to TCJA changes other than the changes to the taxation of foreign earnings.

\section{CONCLUSION}

The recent enactment of the TCJA is a significant change to U.S. corporate tax policy and in particular, significantly reduces repatriation costs of U.S. multinational companies. The TCJA provides a unique setting to examine whether firms increase capital investment or shareholder 
payouts in response to a reduction in internal capital market frictions due to the elimination of repatriation costs. An intent underlying the TCJA is to enable firms to increase economic growth potentially through increased domestic capital investment. This study investigates whether a permanent reduction in repatriation costs created by the TCJA increases spending on shareholder payouts or capital expenditures for firms with higher levels of foreign cash.

Consistent with findings from the prior literature (Blouin and Krull, 2009; Dharmapala et al., 2011; Faulkender and Petersen, 2012; Arena and Kutner, 2015), we find no evidence of an increase in capital expenditures post-TCJA for firms with higher levels of pre-TCJA foreign cash in the broad cross-section, but we do find evidence of an increase in capital expenditures postTCJA for firms with higher levels of pre-TCJA foreign cash when these firms are in marginally weak financial health. We further document that this increase in capital expenditures is a result of domestic capital expenditures and not foreign capital expenditures. Additionally, we find evidence consistent with an increase in shareholder payouts post-TCJA for firms with higher levels of pre-TCJA foreign cash, and we find firms used share repurchases rather than dividends to return cash to shareholders post-TCJA; this result is concentrated in firms with marginally weak financial health as well, and as expected, in firms with high pre-TCJA repatriation costs. We also provide additional analysis using a difference-in-differences model, comparing postTCJA multinational firm expenditures to post-TCJA domestic-only firm expenditures, to ensure our findings are driven by the reduction in repatriation costs and not the other changes included in the TCJA (statutory tax rate decrease, 100 percent bonus depreciation, and/or interest deductibility). The results from the analyses are consistent with our main results confirming our conjecture. 
We make several contributions to the literature. First, our findings should be of use to policymakers as they evaluate the effectiveness of the TCJA in encouraging domestic capital investment. The TCJA created a significant debate regarding its ability to increase domestic investment. Our findings indicate that domestic investment increases only for firms who are in marginally weak financial health. Second, prior research examines the investment consequences of the AJCA and tax reform in both the United Kingdom and Japan, and our results add to this existing stream of literature. Finally, we contribute to the literature on the effect of taxes on firm decision-making. Our findings imply that taxes influence managers' investment decisions. 


\section{REFERENCES}

Aharony, J., and I. Swary. 1980. Quarterly dividend and earnings announcements and stockholders' returns: An empirical analysis. Journal of Finance 35 (1): 1-12.

Albring, S. M. 2006. The effects of the cost of foreign internal funds on the probability that a firm issues domestic debt. Journal of American Tax Association 28 (1): 25-41.

Allen, F., and R. Michaely. 2003. Payout policy. In: Constantinides, G., Harris, M., Stulz, R. (Eds.), Handbook of the Economics of Finance. North-Holland, Amsterdam: 337-429.

Altman, E. 1968. Financial ratios, discriminant analysis and the prediction of corporate bankruptcy. Journal of Finance 23 (4): 589-609.

Amberger, H. J., K. S. Markle, and D. M. P. Samuel. 2018. Repatriation taxes, internal agency conflicts and subsidiary-level investment efficiency. Working paper available at SSRN: https://papers.ssrn.com/sol3/papers.cfm?abstract_id=3138823.

Arena, M. P., and G. W. Kutner. 2015. Territorial tax system reform and corporate financial policies. Review of Financial Studies 28 (8): 2250-2280.

Beyer, B., J. Downes, and E. T. Rapley. 2017. Internal capital market inefficiencies, shareholder payout, and abnormal leverage. Journal of Corporate Finance 43: 39-57.

Biddle, G. C., G. Hilary, and R. S.Verdi. 2009. How does financial reporting quality relate to investment efficiency? Journal of Accounting and Economics 48 (2-3): 112-131.

Billett, M. T., and D. C. Mauer. 2003. Cross-subsidies, external financing constraints, and the contribution of internal capital markets to firm value. Review of Financial Studies 16 (4): $1167-1201$.

Bjornsen, M., J. F. Downes, and T. C. Omer. 2019. The consequences of deviating from financial reporting industry norms: Evidence from the disclosure of foreign cash. Working paper available at SSRN: https://papers.ssrn.com/sol3/papers.cfm?abstract_id=2832216.

Blaylock, B., J. F. Downes, M. Mathis, and S. White. 2019. The effect of repatriation taxes on bond pricing: Evidence from the 2016 election. Working paper.

Bloomberg. 2017. These are the corporate winners and losers in the GOP's final tax bill <http://fortune.com/2017/12/16/gop-tax-bill-winners-and-losers/>

Blouin, J. L., and L. K. Krull. 2009. Bringing it home: A study of the incentives surrounding the repatriation of foreign earnings under the American Jobs Creation Act of 2004. Journal of Accounting Research 47 (4): 1027-1059.

Brav, A., J. Graham, C. Harvey, and R. Michaely. 2005. Payout policy in the 21st century. Journal of Financial Economics 77 (3): 483-527.

Canace, T. G., S. B. Jackson, and T. Ma. 2018. R\&D investments, capital expenditures, and earnings thresholds. Review of Accounting Studies 23 (1): 265-295. 
Clemons, R., and T. Shevlin. 2016. Tax policy debate: increasing the policy impact of academic tax accounting research. Journal of the American Taxation Association 38 (1): 29-37.

Datta, S., R. D’Mello, and M. Iskandar-Datta. 2009. Executive compensation and internal capital market efficiency. Journal of Financial Intermediation 18 (2): 242-258.

Davis, L., and S. Chandra. 2018. U.S. cash repatriation plunges 50\%, defying Trump's tax forecast. Bloomberg News December 19.

DeAngelo, H., L. DeAngelo, and R. Stulz. 2006. Dividend policy and the earned/contributed capital mix: a test of the life-cycle theory. Journal of Financial Economics 81 (2): 227254.

Desai, M. A., C. F. Foley, and J. R. Hines. 2007. Dividend policy inside the multinational firm. Financial Management 36 (1): 5-26.

De Simone, L., and R. Lester. 2018. The effect of foreign cash holdings on internal capital markets and firm financing (October 22, 2018). Stanford University Graduate School of Business Research Paper No. 18-32. Working paper available at SSRN: https://ssrn.com/abstract=3199295.

De Waegenaere, A., and R. Sansing. 2008. Taxation of international investment and accounting valuation. Contemporary Accounting Research 25 (4): 2299-2336.

Dharmapala, D., C. F. Foley, and K. J. Forbes. 2011. Watch what I do, not what I say: The unintended consequences of the Homeland Investment Act. Journal of Finance 66 (3): 753-787.

Dong, Q., Y. Cao, X. Zhao, A. Deshmukh. 2019. Responses of US multinational firms to a temporary repatriation tax holiday: A literature review and synthesis. Journal of Accounting Literature forthcoming.

Edwards, A., T. Kravet, and R. Wilson. 2016. Trapped cash and the profitability of foreign cash acquisitions. Contemporary Accounting Research 33 (1): 44-77.

Fama, E. F., and K. R. French. 2001. Disappearing dividends: changing firm characteristics or lower propensity to pay? Journal of Financial Economics 60 (1): 3-43

Faulkender, M., and M. Petersen. 2012. Investment and capital constraints: Repatriations under the American Jobs Creation Act. Review of Financial Studies 25 (11): 3351-3388.

Foley, C. F., J. C. Hartzell, S. Titman, and G. Twite. 2007. Why do firms hold so much cash? A tax-based explanation. Journal of Financial Economics 86 (3): 579-607.

Garber, J. 2017. Here's what America's biggest companies plan to do with all that cash come back to the U.S. Business Insider December 20.

GDP Ranked by Country 2019. World Population Review, http://worldpopulationreview.com/countries/countries-by-gdp/.

Graham, J. R., M. Hanlon, and T. Shevlin. 2010. Barriers to mobility: The lockout effect of U.S. taxation of worldwide corporate profits. National Tax Journal 63 (4): 1111-1144. 
Grullon, G., B. Paye, S. Underwood, and J. P. Weston. 2011. Has the propensity to pay out declined? Journal of Financial and Quantitative Analysis 46 (1): 1-24.

Guay, W., and J. Harford. 2000. The cash-flow permanence and information content of dividend increases versus repurchase. Journal of Financial Economics 57: 385-415.

Hanlon, M., J. L. Hoopes, and J. B. Slemrod. 2018. Tax reform made me do it! (November 5, 2018). Kenan Institute of Private Enterprise Research Paper No. 18-36. Working paper available at SSRN: https://ssrn.com/abstract=3279253.

Hanlon, M., R. Lester, and R. Verdi. 2015. The effect of repatriation tax costs on U.S. multinational investment. Journal of Financial Economics 116 (1): 179-196.

Hope, O.-K., and W. Thomas. 2008. Managerial empire building and firm disclosure. Journal of Accounting Research 46 (3): 591-626.

Jagannathan, M., C. Stephens, and M. Weisbach. 2000. Financial flexibility and the choice between dividends and stock repurchases. Journal of Financial Economics. 56 (3): 355384.

Jensen, M. 1986. Agency costs of free cash flow, corporate finance and takeovers. The American Economic Review 76 (2): 323-329.

Laplante S., K., and W. L. Nesbit. 2017. The relation among trapped cash, permanently reinvested earnings, and foreign cash. Journal of Corporate Finance 44: 126-148.

Lattman, P., and P. Eavis. 2013. To satisfy its investors, cash-rich Apple borrows money. New York Times, April 30.

Mead, C., and D. Kucera. 2012. eBay skirts cash repatriation with bond issue: Corporate finance. Bloomberg.

Myers, S. 1984. The capital structure puzzle. Journal of Finance 39 (3): 574-592.

Myers, S., and N. Majluf. 1984. Corporate financing decisions when firms have investment information that investors do not. Journal of Financial Economics 13 (2): 187-221.

Nessa, M. L. 2017. Repatriation tax costs and U.S. multinational companies' shareholder payouts. The Accounting Review 92 (4): 217-241.

Nevius, A. M. 2017. How tax overhaul would change business taxes. Journal of Accountancy.

PR Newswire. 2019. S\&P 500 Q4 2018 buybacks set 4th consecutive quarterly record at \$223 billion; 2018 sets record $\$ 806$ billion. https://www.prnewswire.com/news-releases/sp500-q4-2018-buybacks-set-4th-consecutive-quarterly-record-at-223-billion-2018-setsrecord-806-billion-300817734.html (last accessed 5/10/19)

Shin, H., and R. M. Stulz. 1998. Are internal capital markets efficient? Quarterly Journal of Economics 113 (2): 531-552.

Shyam-Sunders, L., and S. Myers. 1999. Testing static tradeoff against pecking order models of capital structure. Journal of Financial Economics 51 (2): 219-244. 
Slemrod, J. 2018. Is this tax reform or just confusion? Journal of Economic Perspectives 32 (4): 73-96.

Stein, J. C. 1997. Internal capital markets and the competition for corporate resources. Journal of Finance 52 (1): 111-134.

Weston, J. F. 1970. Mergers and acquisitions in business planning, Rivista Int. Sci. Econ. Com., (April): 309-320.

Williamson, O. E. 1975. Markets and hierarchies: Analysis and antitrust implications. Collier Macmillan Publishers, Inc. New York.

Whitehouse.gov. 2018. The tax cuts and jobs act. Available at: https://www.whitehouse.gov/wpcontent/uploads/2018/02/WH_CuttingTaxesForAmericanWorkers_Feb2018.pdf 


\section{Table 1}

Summary statistics

\begin{tabular}{lcccccc} 
& $\mathbf{N}$ & Mean & St. Dev. & Q1 & Median & Q3 \\
\hline Total Payout & 1,200 & 0.057 & 0.079 & 0.003 & 0.029 & 0.078 \\
Dividends & 1,200 & 0.016 & 0.024 & 0.000 & 0.002 & 0.023 \\
Repurchases & 1,200 & 0.041 & 0.069 & 0.000 & 0.014 & 0.050 \\
CapEx & 1,200 & 0.042 & 0.043 & 0.017 & 0.030 & 0.053 \\
Post & 1,200 & 0.333 & 0.472 & 0.000 & 0.000 & 1.000 \\
Foreign Cash & 1,200 & 0.084 & 0.085 & 0.025 & 0.056 & 0.110 \\
Domestic Cash & 1,200 & 0.117 & 0.154 & 0.015 & 0.056 & 0.159 \\
Book ETR & 1,200 & 0.211 & 0.195 & 0.055 & 0.203 & 0.293 \\
Cash ETR & 1,200 & 0.198 & 0.190 & 0.053 & 0.179 & 0.271 \\
Loss & 1,200 & 0.230 & 0.421 & 0.000 & 0.000 & 0.000 \\
Size & 1,200 & 7.713 & 1.736 & 6.580 & 7.766 & 8.869 \\
Earnings & 1,200 & 0.036 & 0.129 & 0.009 & 0.049 & 0.089 \\
Cash Flow & 1,200 & 0.105 & 0.105 & 0.059 & 0.101 & 0.151 \\
Leverage & 1,200 & 0.229 & 0.177 & 0.079 & 0.223 & 0.346 \\
MTB & 1,200 & 3.944 & 11.300 & 1.758 & 2.884 & 4.796 \\
Sales Growth & 1,200 & 0.053 & 0.180 & -0.038 & 0.043 & 0.124 \\
CapEx 2014 & 1,200 & 0.039 & 0.036 & 0.017 & 0.029 & 0.050 \\
RD & 1,200 & 0.056 & 0.090 & 0.000 & 0.018 & 0.071 \\
ACQ & 1,200 & 0.051 & 0.128 & 0.000 & 0.001 & 0.035 \\
Firm Age & 1,200 & 3.682 & 0.535 & 3.401 & 3.714 & 4.143 \\
RE/BV & 1,200 & 0.167 & 3.770 & -0.104 & 0.477 & 0.922 \\
Returns & 1,200 & 0.023 & 0.357 & -0.220 & 0.009 & 0.218 \\
Options & 1,200 & 0.013 & 0.106 & -0.022 & 0.000 & 0.015 \\
St. Dev. Earnings & 1,200 & 0.041 & 0.047 & 0.012 & 0.025 & 0.054
\end{tabular}

This table reports summary statistics for the main sample of firm-year observations for the period 2015 - 2018, excluding the year 2017. The 2014 fiscal year-end total assets is used as the scalar in the following variable definitions. Total Payout is the sum of Dividends and Repurchases. Dividends is total dividends paid scaled by total assets, set equal to zero when dividends are missing in Compustat. Repurchases are total repurchases scaled by total assets. A repurchase is identified as a positive value for purchases of common and preferred stock less any decrease in the redemption value of preferred stock in the prior year, or minus the decrease in preferred stock in the prior year, if the redemption value is missing. CapEx is capital expenditures scaled by total assets. Post is equal to one for fiscal years ending in 2018, zero otherwise. Foreign Cash is foreign cash at the end of fiscal year 2014 scaled by total assets. Domestic Cash is total cash minus foreign cash at the end of 2014, scaled by total assets. Book ETR is current federal tax expense scaled by pretax income minus special items, measured at the end of fiscal year 2014. Cash ETR is current taxes paid scaled by pretax income minus special items, measured at the end of fiscal year 2014. Loss is equal to 1 when income before extraordinary items is less than zero and equal to zero otherwise. Size is the natural logarithm of total assets at the end of fiscal year 2014. Earnings is income before extraordinary items scaled by total assets. Cash Flow is equal to operating cash flow scaled by total assets. Leverage is long term debt at the end of fiscal year 2014 scaled by total assets. MTB is market value of shares outstanding divided by the total 
book value. Sales Growth is total sales minus lagged sales, scaled by lagged sales. CapEx 2014 is total fiscal year 2014 capital expenditures scaled by total assets. $R D$ is equal to research and development expense scaled by total assets. $R D$ is equal to zero when missing in Compustat. $A C Q$ is equal to total expenditures on mergers and acquisitions scaled by total assets. $A C Q$ is equal to zero when missing in Compustat. Firm Age is the natural logarithm of the number of years the firm has been in Compustat. $R E / B V$ is the ratio of retained earnings to book value of common equity. Returns is monthly compounded stock return for the two years prior to period $t$. Options is the annual percentage change in total diluted shares outstanding of firm as if no repurchases were made during year t. St. Dev. Earnings is the standard deviation of earnings for the current and previous 4 years. Continuous variables are winsorized at the 1 and 99 percentiles. 
Table 2

Correlation matrix

\begin{tabular}{|c|c|c|c|c|c|c|c|c|c|c|c|c|c|}
\hline & & 1 & 2 & 3 & 4 & 5 & 6 & 7 & 8 & 9 & 10 & 11 & 12 \\
\hline 1 & Total Payout & & 0.569 & 0.886 & 0.018 & 0.244 & 0.100 & -0.099 & 0.180 & 0.278 & -0.410 & 0.292 & 0.526 \\
\hline 2 & Dividends & 0.488 & & 0.245 & 0.055 & 0.100 & 0.032 & -0.232 & 0.184 & 0.246 & -0.351 & 0.345 & 0.381 \\
\hline 3 & Repurchases & 0.933 & 0.164 & & -0.011 & 0.194 & 0.110 & -0.040 & 0.138 & 0.216 & -0.331 & 0.216 & 0.434 \\
\hline 4 & CapEx & 0.016 & 0.004 & 0.018 & & -0.013 & 0.097 & 0.054 & -0.013 & -0.063 & -0.079 & 0.114 & 0.132 \\
\hline 5 & Foreign Cash & 0.242 & 0.050 & 0.260 & -0.062 & & 0.000 & 0.014 & 0.015 & 0.177 & -0.158 & -0.028 & 0.277 \\
\hline 6 & Post & 0.119 & 0.058 & 0.112 & 0.110 & 0.000 & & 0.000 & -0.185 & -0.043 & -0.025 & 0.052 & 0.129 \\
\hline 7 & Domestic Cash & 0.010 & -0.152 & 0.065 & 0.106 & -0.111 & 0.000 & & -0.181 & -0.246 & 0.268 & -0.295 & -0.154 \\
\hline 8 & Book ETR & 0.030 & 0.034 & 0.024 & -0.046 & 0.028 & -0.119 & -0.192 & & 0.482 & -0.308 & 0.085 & 0.224 \\
\hline 9 & Cash 1 & 0.095 & 0.092 & 0.073 & -0.079 & 0.085 & -0.021 & -0.214 & 0.452 & & -0.385 & 0.131 & 0.301 \\
\hline 0 & Loss & -0.256 & -0.266 & -0.195 & -0.026 & -0.137 & -0.025 & 0.346 & -0.096 & -0.160 & & -0.286 & -0.729 \\
\hline 1 & Size & 0.197 & 0.254 & 0.140 & 0.111 & -0.029 & 0.046 & -0.370 & 0.032 & 0.065 & -0.304 & & 0.252 \\
\hline 12 & Earnings & 0.384 & 0.262 & 0.342 & 0.015 & 0.209 & 0.120 & -0.290 & 0.154 & 0.183 & -0.676 & 0.296 & \\
\hline 3 & Cash Flow & 0.483 & 0.283 & 0.446 & 0.286 & 0.185 & 0.125 & -0.071 & 0.080 & 0.065 & -0.424 & 0.264 & 0.636 \\
\hline 14 & Leverage & 0.006 & 0.076 & -0.013 & 0.056 & -0.180 & 0.071 & -0.351 & 0.012 & -0.015 & -0.115 & 0.412 & 0.050 \\
\hline 5 & MTB & 0.089 & 0.055 & 0.078 & 0.016 & -0.058 & & 0.041 & -0.002 & -0.023 & -0.019 & 0.049 & 0.068 \\
\hline 16 & Sales Growth & 0.008 & -0.062 & 0.040 & 0.183 & -0.022 & 0.177 & 0.246 & -0.066 & -0.119 & -0.074 & 0.005 & 0.090 \\
\hline 17 & CapEx 2014 & 0.013 & 0.022 & 0.010 & 0.819 & -0.072 & 0.064 & 0.065 & -0.051 & -0.089 & 0.040 & 0.110 & -0.021 \\
\hline 18 & $R D$ & 0.065 & -0.072 & 0.099 & 0.097 & 0.044 & 0.070 & 0.543 & -0.235 & -0.226 & 0.272 & -0.241 & -0.264 \\
\hline 19 & $A C Q$ & -0.004 & 0.031 & -0.008 & 0.001 & 0.011 & 0.031 & -0.020 & 0.003 & 0.016 & -0.047 & 0.066 & 0.019 \\
\hline 20 & Firm Age & 0.108 & 0.293 & 0.019 & -0.072 & 0.099 & 0.123 & -0.393 & 0.098 & 0.126 & -0.264 & 0.344 & 0.238 \\
\hline 1 & $R E / B V$ & 0.131 & 0.089 & 0.118 & -0.016 & 0.063 & -0.020 & -0.132 & 0.085 & 0.078 & -0.189 & 0.162 & 0.157 \\
\hline 22 & Returns & -0.001 & 0.004 & -0.004 & -0.059 & 0.027 & -0.251 & -0.030 & 0.039 & -0.019 & -0.166 & 0.002 & 0.156 \\
\hline 23 & Options & -0.072 & 0.004 & -0.094 & 0.073 & -0.064 & 0.003 & 0.145 & -0.052 & -0.112 & 0.079 & -0.080 & -0.082 \\
\hline 24 & St. Dev. Earnings & 0.024 & -0.082 & 0.045 & 0.053 & 0.006 & 0.096 & 0.261 & -0.139 & -0.167 & 0.414 & -0.189 & -0.318 \\
\hline 15 & Dividends $t-1$ & 0.409 & 0.886 & 0.138 & 0.000 & 0.047 & 0.048 & -0.171 & 0.038 & 0.099 & -0.250 & 0.236 & 0.235 \\
\hline & Repurchases $t-1$ & 0.612 & 0.157 & 0.643 & -0.030 & 0.280 & -0.034 & -0.004 & 0.044 & 0.066 & -0.205 & 0.152 & 0.317 \\
\hline
\end{tabular}




\begin{tabular}{|c|c|c|c|c|c|c|c|c|c|c|c|c|c|c|c|}
\hline & & 13 & 14 & 15 & 16 & 17 & 18 & 19 & 20 & 21 & 22 & 23 & 24 & 25 & 26 \\
\hline 1 & Total Payout & 0.441 & 0.026 & 0.338 & -0.018 & 0.004 & -0.035 & 0.088 & 0.214 & 0.397 & 0.006 & -0.505 & -0.172 & 0.522 & 0.669 \\
\hline 2 & Dividends & 0.231 & 0.138 & 0.186 & -0.106 & 0.052 & -0.180 & 0.074 & 0.402 & 0.397 & 0.036 & -0.256 & -0.241 & 0.943 & 0.254 \\
\hline 3 & Repurchases & 0.386 & -0.009 & 0.288 & 0.004 & -0.029 & 0.020 & 0.097 & 0.101 & 0.287 & -0.027 & -0.516 & -0.115 & 0.209 & 0.708 \\
\hline 4 & CapEx & 0.330 & 0.072 & 0.137 & 0.175 & 0.868 & 0.048 & -0.015 & -0.008 & -0.080 & -0.044 & 0.102 & 0.057 & 0.034 & -0.013 \\
\hline 5 & Foreign Cash & 0.207 & -0.212 & 0.090 & -0.030 & -0.014 & 0.190 & 0.030 & 0.141 & 0.162 & 0.031 & -0.126 & 0.080 & 0.091 & 0.231 \\
\hline 6 & Post & 0.091 & 0.073 & 0.078 & 0.259 & 0.051 & 0.027 & -0.011 & 0.126 & 0.028 & -0.275 & 0.083 & 0.168 & 0.027 & 0.018 \\
\hline 7 & Domestic Cash & -0.017 & -0.394 & 0.093 & 0.195 & 0.041 & 0.370 & -0.107 & -0.313 & -0.256 & -0.008 & 0.270 & 0.292 & -0.237 & -0.071 \\
\hline 8 & Book ETR & 0.155 & 0.022 & -0.016 & -0.057 & -0.016 & -0.341 & 0.059 & 0.123 & 0.233 & 0.131 & -0.196 & -0.300 & 0.178 & 0.154 \\
\hline 9 & Cash ETR & 0.159 & 0.017 & 0.062 & -0.091 & -0.077 & -0.263 & 0.136 & 0.160 & 0.286 & 0.065 & -0.283 & -0.283 & 0.239 & 0.195 \\
\hline 10 & Loss & -0.453 & -0.124 & -0.222 & -0.133 & -0.003 & 0.171 & -0.163 & -0.219 & -0.366 & -0.191 & 0.246 & 0.428 & -0.313 & -0.306 \\
\hline 11 & Size & 0.189 & 0.451 & 0.189 & -0.002 & 0.102 & -0.243 & 0.144 & 0.355 & 0.326 & -0.002 & -0.294 & -0.202 & 0.331 & 0.232 \\
\hline 12 & Earnings & 0.670 & 0.013 & 0.370 & 0.221 & 0.058 & -0.029 & 0.151 & 0.201 & 0.416 & 0.168 & -0.219 & -0.198 & 0.341 & 0.387 \\
\hline 13 & Cash Flow & & 0.042 & 0.364 & 0.289 & 0.272 & 0.079 & 0.138 & 0.001 & 0.224 & 0.190 & -0.095 & -0.084 & 0.205 & 0.352 \\
\hline 14 & Leverage & 0.047 & & 0.086 & -0.051 & 0.063 & -0.270 & 0.007 & 0.125 & 0.101 & -0.017 & -0.116 & -0.145 & 0.151 & 0.006 \\
\hline 16 & Sales Growth & 0.217 & -0.011 & 0.079 & & 0.028 & 0.197 & 0.188 & -0.198 & -0.064 & 0.070 & 0.344 & 0.000 & -0.129 & -0.073 \\
\hline 17 & CapEx 2014 & 0.258 & 0.060 & 0.010 & 0.028 & & 0.034 & -0.069 & 0.005 & -0.077 & -0.038 & 0.057 & 0.110 & 0.046 & -0.009 \\
\hline 18 & $R D$ & 0.053 & -0.268 & 0.104 & 0.215 & 0.104 & & -0.041 & -0.130 & -0.208 & 0.024 & 0.222 & 0.255 & -0.188 & 0.001 \\
\hline 19 & $A C Q$ & 0.112 & -0.009 & 0.025 & 0.271 & -0.040 & 0.095 & & 0.039 & 0.112 & 0.000 & -0.011 & -0.186 & 0.060 & 0.110 \\
\hline 20 & Firm Age & 0.024 & 0.092 & -0.041 & -0.241 & -0.047 & -0.263 & -0.011 & & 0.412 & -0.013 & -0.230 & -0.154 & 0.419 & 0.138 \\
\hline 21 & $R E / B V$ & 0.155 & 0.020 & 0.117 & 0.019 & -0.024 & -0.187 & 0.034 & 0.150 & & 0.067 & -0.335 & -0.260 & 0.393 & 0.317 \\
\hline 22 & Returns & 0.167 & -0.009 & -0.016 & 0.082 & -0.042 & -0.011 & -0.009 & -0.013 & 0.048 & & 0.014 & -0.100 & 0.037 & 0.090 \\
\hline 23 & Options & -0.040 & -0.048 & 0.048 & 0.281 & 0.021 & 0.141 & 0.128 & -0.100 & -0.052 & 0.016 & & 0.223 & -0.248 & -0.556 \\
\hline 24 & St. Dev. Earnings & -0.061 & -0.127 & -0.036 & -0.013 & 0.105 & 0.369 & -0.001 & -0.182 & -0.109 & -0.065 & 0.105 & & -0.233 & -0.131 \\
\hline 25 & Dividends $t-1$ & 0.241 & 0.099 & 0.034 & -0.081 & 0.027 & -0.094 & 0.018 & 0.308 & 0.085 & -0.013 & -0.025 & -0.098 & & 0.236 \\
\hline 26 & Repurchases $t$-1 & 0.402 & 0.009 & 0.013 & -0.045 & -0.013 & 0.054 & 0.009 & 0.056 & 0.110 & 0.069 & -0.127 & -0.017 & 0.140 & \\
\hline
\end{tabular}


This table presents Pearson (Spearman) correlations above (below) the diagonal. All correlations that are bold and italicized are significant at the 10 percent level. The 2014 fiscal year-end total assets is used as the scalar in the following variable definitions. Total Payout is the sum of Dividends and Repurchases. Dividends is total dividends paid scaled by total assets, set equal to zero when dividends are missing in Compustat. Repurchases are total repurchases scaled by total assets. A repurchase is identified as a positive value for purchases of common and preferred stock less any decrease in the redemption value of preferred stock in the prior year, or minus the decrease in preferred stock in the prior year, if the redemption value is missing. CapEx is capital expenditures scaled by total assets. Post is equal to one for fiscal years ending in 2018, zero otherwise. Foreign Cash is foreign cash at the end of fiscal year 2014 scaled by total assets.

Domestic Cash is total cash minus foreign cash at the end of 2014, scaled by total assets. Book ETR is current federal tax expense scaled by pretax income minus special items, measured at the end of fiscal year 2014. Cash ETR is current taxes paid scaled by pretax income minus special items, measured at the end of fiscal year 2014. Loss is equal to 1 when income before extraordinary items is less than zero and equal to zero otherwise. Size is the natural logarithm of total assets at the end of fiscal year 2014. Earnings is income before extraordinary items scaled by total assets. Cash Flow is equal to operating cash flow scaled by total assets. Leverage is long term debt at the end of fiscal year 2014 scaled by total assets. MTB is market value of shares outstanding divided by the total book value. Sales Growth is total sales minus lagged sales, scaled by lagged sales. CapEx 2014 is total fiscal year 2014 capital expenditures scaled by total assets. $R D$ is equal to research and development expense scaled by total assets. $R D$ is equal to zero when missing in Compustat. $A C Q$ is equal to total expenditures on mergers and acquisitions scaled by total assets. $A C Q$ is equal to zero when missing in Compustat. Firm Age is the natural logarithm of the number of years the firm has been in Compustat. $R E / B V$ is the ratio of retained earnings to book value of common equity. Returns is monthly compounded stock return for the two years prior to period t. Options is the annual percentage change in total diluted shares outstanding of firm as if no repurchases were made during year $t$. St. Dev. Earnings is the standard deviation of earnings for the current and previous 4 years. Continuous variables are winsorized at the 1 and 99 percentiles. 


\section{Table 3}

The use of foreign cash following the TCJA

\begin{tabular}{|c|c|c|c|c|}
\hline & $\begin{array}{c}\text { (1) } \\
\text { Total Payout }\end{array}$ & $\begin{array}{c}(2) \\
\text { Dividends }\end{array}$ & $\begin{array}{c}\text { (3) } \\
\text { Repurchases }\end{array}$ & $\begin{array}{c}\text { (4) } \\
\text { CapEx }\end{array}$ \\
\hline Post & $\begin{array}{l}0.005 \\
(0.79)\end{array}$ & $\begin{array}{l}0.000 \\
(0.16)\end{array}$ & $\begin{array}{l}0.006 \\
(1.03)\end{array}$ & $\begin{array}{c}0.006^{* * *} \\
(2.79)\end{array}$ \\
\hline Foreign Cash & $\begin{array}{l}0.037 \\
(1.43)\end{array}$ & $\begin{array}{l}-0.009 \\
(-0.90)\end{array}$ & $\begin{array}{l}0.040 \\
(1.53)\end{array}$ & $\begin{array}{c}0.007 \\
(0.78)\end{array}$ \\
\hline Foreign Cash $\times$ Post & $\begin{array}{l}\text { 0.126* } \\
(1.95)\end{array}$ & $\begin{array}{l}0.009 \\
(0.66)\end{array}$ & $\begin{array}{c}\text { 0.116* } \\
(1.78)\end{array}$ & $\begin{array}{l}-0.023 \\
(-1.55)\end{array}$ \\
\hline Domestic Cash & $\begin{array}{c}0.071^{* * * *} \\
(2.90)\end{array}$ & $\begin{array}{l}-0.003 \\
(-0.47)\end{array}$ & $\begin{array}{c}0.072^{* * *} \\
(3.02)\end{array}$ & $\begin{array}{c}0.018^{* * *} \\
(2.32)\end{array}$ \\
\hline Book ETR & $\begin{array}{l}-0.006 \\
(-0.63)\end{array}$ & $\begin{array}{l}0.001 \\
(0.22)\end{array}$ & $\begin{array}{l}-0.004 \\
(-0.38)\end{array}$ & $\begin{array}{l}0.002 \\
(0.72)\end{array}$ \\
\hline Cash ETR & $\begin{array}{l}0.017 \\
(1.56)\end{array}$ & $\begin{array}{l}0.002 \\
(0.54)\end{array}$ & $\begin{array}{l}0.015 \\
(1.27)\end{array}$ & $\begin{array}{l}0.003 \\
(0.91)\end{array}$ \\
\hline Loss & $\begin{array}{l}-0.009 \\
(-1.31)\end{array}$ & $\begin{array}{c}-0.008^{* * * *} \\
(-3.33)\end{array}$ & $\begin{array}{l}-0.010 \\
(-1.49)\end{array}$ & $\begin{array}{c}-0.006 * \\
(-1.84)\end{array}$ \\
\hline Size & $\begin{array}{l}0.003^{*} \\
(1.85)\end{array}$ & $\begin{array}{c}0.002^{* * * *} \\
(2.99)\end{array}$ & $\begin{array}{l}0.002 \\
(1.47)\end{array}$ & $\begin{array}{l}0.001 \\
(1.37)\end{array}$ \\
\hline Earnings & $\begin{array}{l}0.035 \\
(0.73)\end{array}$ & $\begin{array}{l}-0.005 \\
(-0.50)\end{array}$ & $\begin{array}{l}0.038 \\
(0.88)\end{array}$ & $\begin{array}{l}-0.026 \\
(-1.35)\end{array}$ \\
\hline Cash Flow & $\begin{array}{c}0.189^{* * *} \\
(4.67)\end{array}$ & $\begin{array}{c}0.034^{* *} \\
(2.24)\end{array}$ & $\begin{array}{c}0.164^{* * *} \\
(4.45)\end{array}$ & $\begin{array}{c}0.039^{* *} \\
(2.05)\end{array}$ \\
\hline Leverage & $\begin{array}{l}-0.005 \\
(-0.34)\end{array}$ & $\begin{array}{c}-0.011^{* * * *} \\
(-2.61)\end{array}$ & $\begin{array}{l}0.005 \\
(0.34)\end{array}$ & $\begin{array}{l}-0.004 \\
(-0.77)\end{array}$ \\
\hline$M T B$ & $\begin{array}{l}0.000 \\
(1.32)\end{array}$ & $\begin{array}{l}0.000 \\
(0.75)\end{array}$ & $\begin{array}{l}0.000 \\
(1.03)\end{array}$ & $\begin{array}{l}0.000 \\
(0.38)\end{array}$ \\
\hline Sales Growth & $\begin{array}{l}-0.025^{*} \\
(-1.72)\end{array}$ & $\begin{array}{l}-0.008 \\
(-1.38)\end{array}$ & $\begin{array}{l}-0.015 \\
(-1.24)\end{array}$ & $\begin{array}{c}0.028^{* * * *} \\
(5.12)\end{array}$ \\
\hline CapEx 2014 & $\begin{array}{c}-0.174^{* *} \\
(-2.42)\end{array}$ & $\begin{array}{c}-0.047^{* *} \\
(-2.09)\end{array}$ & $\begin{array}{l}-0.144^{*} \\
(-1.95)\end{array}$ & $\begin{array}{c}0.933^{* * *} \\
(16.41)\end{array}$ \\
\hline$R D$ & $\begin{array}{l}-0.018 \\
(-0.50)\end{array}$ & $\begin{array}{c}-0.027^{* *} \\
(-2.57)\end{array}$ & $\begin{array}{l}-0.007 \\
(-0.19)\end{array}$ & $\begin{array}{l}-0.024^{*} \\
(-1.66)\end{array}$ \\
\hline$A C Q$ & $\begin{array}{l}-0.017 \\
(-1.34)\end{array}$ & $\begin{array}{l}0.005 \\
(1.29)\end{array}$ & $\begin{array}{l}-0.015 \\
(-1.18)\end{array}$ & $\begin{array}{l}-0.002 \\
(-0.48)\end{array}$ \\
\hline Firm Age & $\begin{array}{l}0.008^{*} \\
(1.80)\end{array}$ & $\begin{array}{l}0.004^{*} \\
(1.93)\end{array}$ & $\begin{array}{l}0.006 \\
(1.43)\end{array}$ & \\
\hline$R E / B V$ & $\begin{array}{c}0.001 \\
(1.62)\end{array}$ & $\begin{array}{l}0.000 \\
(0.47)\end{array}$ & $\begin{array}{l}0.001^{*} \\
(1.67)\end{array}$ & \\
\hline Returns & $\begin{array}{c}-0.013^{* *} \\
(-2.42)\end{array}$ & $\begin{array}{l}0.002 \\
(1.05)\end{array}$ & $\begin{array}{c}-0.018^{* * *} \\
(-3.27)\end{array}$ & \\
\hline Options & $\begin{array}{l}-0.003 \\
(-0.16)\end{array}$ & $\begin{array}{l}0.010 \\
(1.59)\end{array}$ & $\begin{array}{l}-0.028 \\
(-1.35)\end{array}$ & \\
\hline St. Dev. Earnings & $\begin{array}{c}0.158^{* * * *} \\
(2.84)\end{array}$ & $\begin{array}{l}0.005 \\
(0.28)\end{array}$ & $\begin{array}{c}0.129^{* * *} \\
(2.50)\end{array}$ & \\
\hline Dividends Lag & $\begin{array}{c}0.932^{* * * *} \\
(7.66)\end{array}$ & $\begin{array}{l}1.063^{* * * *} \\
(16.94)\end{array}$ & $\begin{array}{l}-0.064 \\
(-0.64)\end{array}$ & \\
\hline Repurchase Lag & $\begin{array}{c}0.593^{* * *} \\
(10.99)\end{array}$ & $\begin{array}{l}-0.012 \\
(-0.96)\end{array}$ & $\begin{array}{c}0.624^{* * *} \\
(11.70)\end{array}$ & \\
\hline Intercept & $\begin{array}{c}-0.065^{* * * *} \\
(-3.01)\end{array}$ & $\begin{array}{c}-0.028^{* * * *} \\
(-2.64)\end{array}$ & $\begin{array}{c}-0.070^{* * * *} \\
(-2.89)\end{array}$ & $\begin{array}{l}-0.010 \\
(-1.15)\end{array}$ \\
\hline $\begin{array}{l}N \\
\operatorname{adj} . R^{2}\end{array}$ & 1200 & 1200 & 1200 & $\begin{array}{c}1200 \\
0.7133\end{array}$ \\
\hline Log Likelihood & 1383.798 & 1438.774 & 1197.879 & 2842.585 \\
\hline
\end{tabular}


This table presents estimates from panel regressions on a sample of multinational firms explaining firm-level annual expenditure for the period 2015 - 2018, excluding 2017. The 2014 fiscal year-end total assets is used as the scalar in the following variable definitions. Total Payout is the sum of Dividends and Repurchases. Dividends is total dividends paid scaled by total assets, set equal to zero when dividends are missing in Compustat. Repurchases are total repurchases scaled by total assets. A repurchase is identified as a positive value for purchases of common and preferred stock less any decrease in the redemption value of preferred stock in the prior year, or minus the decrease in preferred stock in the prior year, if the redemption value is missing. CapEx is capital expenditures scaled by total assets. Post is equal to one for fiscal years ending in 2018, zero otherwise. Foreign Cash is foreign cash at the end of fiscal year 2014 scaled by total assets. Domestic Cash is total cash minus foreign cash at the end of 2014, scaled by total assets. Book ETR is current federal tax expense scaled by pretax income minus special items, measured at the end of fiscal year 2014. Cash ETR is current taxes paid scaled by pretax income minus special items, measured at the end of fiscal year 2014. Loss is equal to 1 when income before extraordinary items is less than zero and equal to zero otherwise. Size is the natural logarithm of total assets at the end of fiscal year 2014. Earnings is income before extraordinary items scaled by total assets. Cash Flow is equal to operating cash flow scaled by total assets. Leverage is long term debt at the end of fiscal year 2014 scaled by total assets. MTB is market value of shares outstanding divided by the total book value. Sales Growth is total sales minus lagged sales, scaled by lagged sales. CapEx 2014 is total fiscal year 2014 capital expenditures scaled by total assets. $R D$ is equal to research and development expense scaled by total assets. $R D$ is equal to zero when missing in Compustat. $A C Q$ is equal to total expenditures on mergers and acquisitions scaled by total assets. $A C Q$ is equal to zero when missing in Compustat. Firm Age is the natural logarithm of the number of years the firm has been in Compustat. $R E / B V$ is the ratio of retained earnings to book value of common equity. Returns is monthly compounded stock return for the two years prior to period $t$. Options is the annual percentage change in total diluted shares outstanding of firm as if no repurchases were made during year $t$. St. Dev. Earnings is the standard deviation of earnings for the current and previous 4 years.

Continuous variables are winsorized at the 1 and 99 percentiles. Two-digit SIC code industry fixed effects are included. $* * *, * *, *$ represent significance at the $0.01,0.05,0.10$ two-tailed significance levels. 


\section{Table 4}

Repatriation costs and the use of foreign cash following the TCJA

\begin{tabular}{|c|c|c|c|c|}
\hline & $\begin{array}{c}\text { (1) } \\
\text { Repurchases } \\
\text { High Repat Costs }\end{array}$ & $\begin{array}{c}(2) \\
\text { Repurchases } \\
\text { Low Repat Costs }\end{array}$ & $\begin{array}{c}\text { (3) } \\
\text { CapEx } \\
\text { High Repat Costs }\end{array}$ & $\begin{array}{c}\text { (4) } \\
\text { CapEx } \\
\text { Low Repat Costs }\end{array}$ \\
\hline Post & $\begin{array}{l}-0.008 \\
(-0.79)\end{array}$ & $\begin{array}{l}0.016^{* * *} \\
(2.29)\end{array}$ & $\begin{array}{l}0.004 \\
(1.29)\end{array}$ & $\begin{array}{c}0.008^{* * *} \\
(2.55)\end{array}$ \\
\hline Foreign Cash & $\begin{array}{l}0.060^{*} \\
(1.86)\end{array}$ & $\begin{array}{l}0.058 \\
(0.95)\end{array}$ & $\begin{array}{l}-0.009 \\
(-0.89)\end{array}$ & $\begin{array}{l}0.029^{*} \\
(1.71)\end{array}$ \\
\hline Foreign Cash $\times$ Post & $\begin{array}{c}0.193^{* *} \\
(2.50)\end{array}$ & $\begin{array}{l}-0.038 \\
(-0.36)\end{array}$ & $\begin{array}{l}-0.008 \\
(-0.50)\end{array}$ & $\begin{array}{l}-0.056 \\
(-1.47)\end{array}$ \\
\hline Domestic Cash & $\begin{array}{l}0.007 \\
(0.25)\end{array}$ & $\begin{array}{c}0.103^{* * *} \\
(3.06)\end{array}$ & $\begin{array}{l}0.011 \\
(0.67)\end{array}$ & $\begin{array}{c}0.020^{* * *} \\
(2.07)\end{array}$ \\
\hline Book ETR & $\begin{array}{l}-0.014 \\
(-0.96)\end{array}$ & $\begin{array}{l}0.010 \\
(0.72)\end{array}$ & $\begin{array}{l}0.003 \\
(0.67)\end{array}$ & $\begin{array}{l}0.003 \\
(0.61)\end{array}$ \\
\hline Cash ETR & $\begin{array}{l}0.010 \\
(0.65)\end{array}$ & $\begin{array}{l}0.020 \\
(1.29)\end{array}$ & $\begin{array}{l}0.008 \\
(0.98)\end{array}$ & $\begin{array}{l}0.001 \\
(0.39)\end{array}$ \\
\hline Loss & $\begin{array}{l}-0.019^{*} \\
(-1.76)\end{array}$ & $\begin{array}{l}-0.003 \\
(-0.33)\end{array}$ & $\begin{array}{l}-0.007^{*} \\
(-1.72)\end{array}$ & $\begin{array}{l}-0.003 \\
(-0.66)\end{array}$ \\
\hline Size & $\begin{array}{l}0.003^{*} \\
(1.92)\end{array}$ & $\begin{array}{l}0.000 \\
(0.19)\end{array}$ & $\begin{array}{l}-0.000 \\
(-0.43)\end{array}$ & $\begin{array}{c}0.002^{* * *} \\
(2.09)\end{array}$ \\
\hline Earnings & $\begin{array}{l}-0.048 \\
(-0.80)\end{array}$ & $\begin{array}{c}0.109^{* * *} \\
(2.47)\end{array}$ & $\begin{array}{l}-0.009 \\
(-0.52)\end{array}$ & $\begin{array}{l}-0.032 \\
(-1.22)\end{array}$ \\
\hline Cash Flow & $\begin{array}{c}0.232^{* * * *} \\
(3.85)\end{array}$ & $\begin{array}{c}0.125^{\text {**** }} \\
(3.39)\end{array}$ & $\begin{array}{l}0.018 \\
(0.72)\end{array}$ & $\begin{array}{l}0.048^{*} \\
(1.83)\end{array}$ \\
\hline Leverage & $\begin{array}{l}0.026 \\
(1.22)\end{array}$ & $\begin{array}{l}0.014 \\
(0.71)\end{array}$ & $\begin{array}{l}-0.007 \\
(-0.92)\end{array}$ & $\begin{array}{l}-0.004 \\
(-0.57)\end{array}$ \\
\hline$M T B$ & $\begin{array}{l}-0.000 \\
(-0.08)\end{array}$ & $\begin{array}{l}0.000 \\
(0.68)\end{array}$ & $\begin{array}{l}0.000 \\
(0.75)\end{array}$ & $\begin{array}{l}-0.000 \\
(-0.26)\end{array}$ \\
\hline Sales Growth & $\begin{array}{l}-0.024 \\
(-1.14)\end{array}$ & $\begin{array}{l}-0.007 \\
(-0.49)\end{array}$ & $\begin{array}{c}0.030^{* * * *} \\
(4.17)\end{array}$ & $\begin{array}{c}0.027^{* * * *} \\
(3.84)\end{array}$ \\
\hline CapEx 2014 & $\begin{array}{l}-0.081 \\
(-0.64)\end{array}$ & $\begin{array}{l}-0.159^{*} \\
(-1.76)\end{array}$ & $\begin{array}{c}0.783^{* * *} \\
(10.78)\end{array}$ & $\begin{array}{c}0.990^{* * *} \\
(11.36)\end{array}$ \\
\hline$R D$ & $\begin{array}{l}0.035 \\
(0.62)\end{array}$ & $\begin{array}{l}-0.035 \\
(-0.80)\end{array}$ & $\begin{array}{l}-0.013 \\
(-0.70)\end{array}$ & $\begin{array}{l}-0.028 \\
(-1.43)\end{array}$ \\
\hline$A C Q$ & $\begin{array}{l}-0.013 \\
(-0.84)\end{array}$ & $\begin{array}{l}-0.026 \\
(-1.46)\end{array}$ & $\begin{array}{l}-0.002 \\
(-0.36)\end{array}$ & $\begin{array}{l}-0.001 \\
(-0.13)\end{array}$ \\
\hline Firm Age & $\begin{array}{l}0.005 \\
(0.64)\end{array}$ & $\begin{array}{l}0.007 \\
(1.46)\end{array}$ & & \\
\hline$R E / B V$ & $\begin{array}{c}0.003^{* * * *} \\
(3.17)\end{array}$ & $\begin{array}{l}0.000 \\
(0.42)\end{array}$ & & \\
\hline Returns & $\begin{array}{c}-0.022^{* *} \\
(-2.16)\end{array}$ & $\begin{array}{c}-0.018^{* * *} \\
(-3.05)\end{array}$ & & \\
\hline Options & $\begin{array}{l}-0.034 \\
(-1.21)\end{array}$ & $\begin{array}{l}-0.033 \\
(-1.19)\end{array}$ & & \\
\hline St. Dev. Earnings & $\begin{array}{l}0.056 \\
(0.69)\end{array}$ & $\begin{array}{c}0.195^{* * *} \\
(2.78)\end{array}$ & & \\
\hline Dividends Lag & $\begin{array}{l}-0.028 \\
(-0.22)\end{array}$ & $\begin{array}{l}-0.073 \\
(-0.54)\end{array}$ & & \\
\hline Repurchase Lag & $\begin{array}{c}0.535^{* * *} \\
(7.88)\end{array}$ & $\begin{array}{c}0.689^{* * * *} \\
(8.20)\end{array}$ & & \\
\hline Intercept & $\begin{array}{c}-0.075^{*} \\
(-1.78)\end{array}$ & $\begin{array}{c}-0.080^{* *} \\
(-2.57)\end{array}$ & $\begin{array}{l}0.005 \\
(0.28) \\
\end{array}$ & $\begin{array}{c}-0.023^{\text {** }} \\
(-2.15)\end{array}$ \\
\hline $\begin{array}{l}N \\
\text { adj. } R^{2}\end{array}$ & 600 & 600 & $\begin{array}{c}600 \\
0.6497\end{array}$ & $\begin{array}{c}600 \\
0.7599\end{array}$ \\
\hline Log Likelihood & 634.652 & 607.659 & 1477.588 & 1409.601 \\
\hline
\end{tabular}


This table presents estimates from panel regressions on a sample of multinational firms explaining firm-level annual expenditure for the period 2015 - 2018, excluding 2017. Columns 1 and 3 (2 and 4) include firms that have greater or equal (less than) the sample median of repatriation costs (0.0046). The 2014 fiscal year-end total assets is used as the scalar in the following variable definitions. Total Payout is the sum of Dividends and Repurchases. Dividends is total dividends paid scaled by total assets, set equal to zero when dividends are missing in Compustat. Repurchases are total repurchases scaled by total assets. A repurchase is identified as a positive value for purchases of common and preferred stock less any decrease in the redemption value of preferred stock in the prior year, or minus the decrease in preferred stock in the prior year, if the redemption value is missing. CapEx is capital expenditures scaled by total assets. Post is equal to one for fiscal years ending in 2018, zero otherwise. Foreign Cash is foreign cash at the end of fiscal year 2014 scaled by total assets. Domestic Cash is total cash minus foreign cash at the end of 2014 , scaled by total assets. Book ETR is current federal tax expense scaled by pretax income minus special items, measured at the end of fiscal year 2014. Cash ETR is current taxes paid scaled by pretax income minus special items, measured at the end of fiscal year 2014. Loss is equal to 1 when income before extraordinary items is less than zero and equal to zero otherwise. Size is the natural logarithm of total assets at the end of fiscal year 2014. Earnings is income before extraordinary items scaled by total assets. Cash Flow is equal to operating cash flow scaled by total assets. Leverage is long term debt at the end of fiscal year 2014 scaled by total assets. MTB is market value of shares outstanding divided by the total book value. Sales Growth is total sales minus lagged sales, scaled by lagged sales. CapEx 2014 is total fiscal year 2014 capital expenditures scaled by total assets. $R D$ is equal to research and development expense scaled by total assets. $R D$ is equal to zero when missing in Compustat. $A C Q$ is equal to total expenditures on mergers and acquisitions scaled by total assets. $A C Q$ is equal to zero when missing in Compustat. Firm Age is the natural logarithm of the number of years the firm has been in Compustat. $R E / B V$ is the ratio of retained earnings to book value of common equity. Returns is monthly compounded stock return for the two years prior to period $t$. Options is the annual percentage change in total diluted shares outstanding of firm as if no repurchases were made during year $t$. St. Dev. Earnings is the standard deviation of earnings for the current and previous 4 years. Continuous variables are winsorized at the 1 and 99 percentiles. Two-digit SIC code industry fixed effects are included. $* * *, * * *$ represent significance at the $0.01,0.05,0.10$ two-tailed significance levels. 
Table 5

Financial health and the use of foreign cash following the TCJA

\begin{tabular}{|c|c|c|c|c|c|c|c|c|}
\hline & (1) & (2) & (3) & (4) & (5) & (6) & (7) & (8) \\
\hline & \multicolumn{4}{|c|}{ Repurchases } & \multicolumn{4}{|c|}{ CapEx } \\
\hline & $\begin{array}{l}\text { Weak } \\
\text { Health }\end{array}$ & $\begin{array}{c}\text { Marginal } \\
\text { Weak Health }\end{array}$ & $\begin{array}{c}\text { Marginal } \\
\text { Strong Health }\end{array}$ & $\begin{array}{l}\text { Strong } \\
\text { Health }\end{array}$ & $\begin{array}{l}\text { Weak } \\
\text { Health }\end{array}$ & $\begin{array}{c}\text { Marginal } \\
\text { Weak Health }\end{array}$ & $\begin{array}{c}\text { Marginal } \\
\text { Strong Health }\end{array}$ & $\begin{array}{l}\text { Strong } \\
\text { Health }\end{array}$ \\
\hline Post & $\begin{array}{l}0.009 \\
(1.32)\end{array}$ & $\begin{array}{c}-0.002 \\
(-0.26)\end{array}$ & $\begin{array}{c}0.009 \\
(1.10)\end{array}$ & $\begin{array}{c}0.027^{* * *} \\
(2.67)\end{array}$ & $\begin{array}{c}0.008^{* *} \\
(2.36)\end{array}$ & $\begin{array}{l}-0.003 \\
(-0.75)\end{array}$ & $\begin{array}{l}0.007 \\
(1.08)\end{array}$ & $\begin{array}{c}0.021^{* *} \\
(2.16)\end{array}$ \\
\hline Foreign Cash & $\begin{array}{l}0.132^{* *} \\
(2.10)\end{array}$ & $\begin{array}{l}-0.036 \\
(-0.73)\end{array}$ & $\begin{array}{l}0.005 \\
(0.13)\end{array}$ & $\begin{array}{l}0.062 \\
(1.40)\end{array}$ & $\begin{array}{l}0.055 \\
(1.59)\end{array}$ & $\begin{array}{c}-0.037^{* *} \\
(-2.33)\end{array}$ & $\begin{array}{l}0.034 \\
(0.98)\end{array}$ & $\begin{array}{l}-0.015 \\
(-0.52)\end{array}$ \\
\hline Foreign Cash $\times$ Post & $\begin{array}{l}-0.053 \\
(-0.62)\end{array}$ & $\begin{array}{l}0.127^{*} \\
(1.87)\end{array}$ & $\begin{array}{r}0.009 \\
(0.13)\end{array}$ & $\begin{array}{l}-0.062 \\
(-0.80)\end{array}$ & $\begin{array}{l}-0.026 \\
(-0.36)\end{array}$ & $\begin{array}{c}0.069^{* * *} \\
(2.49)\end{array}$ & $\begin{array}{l}-0.056 \\
(-1.12)\end{array}$ & $\begin{array}{l}-0.096 \\
(-1.57)\end{array}$ \\
\hline Domestic Cash & $\begin{array}{l}0.064^{* *} \\
(2.08)\end{array}$ & $\begin{array}{l}0.053^{* *} \\
(2.17)\end{array}$ & $\begin{array}{l}0.022 \\
(0.63)\end{array}$ & $\begin{array}{l}0.062^{* *} \\
(2.24)\end{array}$ & $\begin{array}{l}-0.005 \\
(-0.21)\end{array}$ & $\begin{array}{l}0.019 \\
(1.15)\end{array}$ & $\begin{array}{l}0.035 \\
(1.21)\end{array}$ & $\begin{array}{l}0.004 \\
(0.18)\end{array}$ \\
\hline Book ETR & $\begin{array}{l}-0.014 \\
(-1.51)\end{array}$ & $\begin{array}{l}-0.004 \\
(-0.43)\end{array}$ & $\begin{array}{l}0.027 \\
(1.19)\end{array}$ & $\begin{array}{l}0.028 \\
(1.50)\end{array}$ & $\begin{array}{l}0.003 \\
(0.44)\end{array}$ & $\begin{array}{l}0.006 \\
(1.24)\end{array}$ & $\begin{array}{l}-0.002 \\
(-0.26)\end{array}$ & $\begin{array}{l}0.002 \\
(0.15)\end{array}$ \\
\hline Cash ETR & $\begin{array}{l}-0.004 \\
(-0.47)\end{array}$ & $\begin{array}{l}0.001 \\
(0.10)\end{array}$ & $\begin{array}{l}0.017 \\
(1.05)\end{array}$ & $\begin{array}{l}0.008 \\
(0.35)\end{array}$ & $\begin{array}{l}0.002 \\
(0.25)\end{array}$ & $\begin{array}{l}-0.003 \\
(-0.51)\end{array}$ & $\begin{array}{l}0.010 \\
(1.18)\end{array}$ & $\begin{array}{l}-0.006 \\
(-0.68)\end{array}$ \\
\hline Loss & $\begin{array}{l}-0.011 \\
(-1.59)\end{array}$ & $\begin{array}{l}0.017^{* * *} \\
(2.32)\end{array}$ & $\begin{array}{l}-0.005 \\
(-0.48)\end{array}$ & $\begin{array}{l}-0.010 \\
(-0.67)\end{array}$ & $\begin{array}{l}-0.004 \\
(-0.75)\end{array}$ & $\begin{array}{l}0.001 \\
(0.21)\end{array}$ & $\begin{array}{l}0.002 \\
(0.32)\end{array}$ & $\begin{array}{c}-0.027^{* * * *} \\
(-2.60)\end{array}$ \\
\hline Size & $\begin{array}{l}0.000 \\
(0.15)\end{array}$ & $\begin{array}{l}0.004^{* * *} \\
(2.39)\end{array}$ & $\begin{array}{l}0.003 \\
(1.56)\end{array}$ & $\begin{array}{l}0.004 \\
(1.46)\end{array}$ & $\begin{array}{l}-0.000 \\
(-0.13)\end{array}$ & $\begin{array}{l}0.001 \\
(0.89)\end{array}$ & $\begin{array}{l}0.003^{*} \\
(1.79)\end{array}$ & $\begin{array}{l}0.002 \\
(0.90)\end{array}$ \\
\hline Earnings & $\begin{array}{l}-0.031 \\
(-0.71)\end{array}$ & $\begin{array}{c}0.153^{* * *} \\
(3.61)\end{array}$ & $\begin{array}{l}0.036 \\
(1.00)\end{array}$ & $\begin{array}{l}0.025 \\
(0.54)\end{array}$ & $\begin{array}{l}-0.006 \\
(-0.40)\end{array}$ & $\begin{array}{l}0.004 \\
(0.31)\end{array}$ & $\begin{array}{l}0.000 \\
(0.00)\end{array}$ & $\begin{array}{l}-0.054 \\
(-1.03)\end{array}$ \\
\hline Cash Flow & $\begin{array}{l}0.148^{* * *} \\
(2.53)\end{array}$ & $\begin{array}{l}0.103^{* *} \\
(2.43)\end{array}$ & $\begin{array}{l}0.102^{*} \\
(1.71)\end{array}$ & $\begin{array}{l}0.095 \\
(1.50)\end{array}$ & $\begin{array}{l}0.031 \\
(0.90)\end{array}$ & $\begin{array}{l}0.023 \\
(0.78)\end{array}$ & $\begin{array}{l}0.026 \\
(0.29)\end{array}$ & $\begin{array}{l}0.007 \\
(0.13)\end{array}$ \\
\hline Leverage & $\begin{array}{l}0.037^{*} \\
(1.95)\end{array}$ & $\begin{array}{l}-0.013 \\
(-0.74)\end{array}$ & $\begin{array}{l}-0.029 \\
(-1.33)\end{array}$ & $\begin{array}{l}0.035 \\
(1.21)\end{array}$ & $\begin{array}{l}-0.006 \\
(-0.44)\end{array}$ & $\begin{array}{l}0.004 \\
(0.42)\end{array}$ & $\begin{array}{l}-0.021 \\
(-1.40)\end{array}$ & $\begin{array}{l}0.001 \\
(0.05)\end{array}$ \\
\hline$M T B$ & $\begin{array}{l}0.000 \\
(0.39)\end{array}$ & $\begin{array}{l}-0.000 \\
(-0.25)\end{array}$ & $\begin{array}{c}0.005^{* * *} \\
(4.03)\end{array}$ & $\begin{array}{l}0.001 \\
(0.64)\end{array}$ & $\begin{array}{l}0.000 \\
(0.26)\end{array}$ & $\begin{array}{l}-0.000 \\
(-0.36)\end{array}$ & $\begin{array}{c}0.003^{* * *} \\
(2.67)\end{array}$ & $\begin{array}{l}0.001 \\
(0.74)\end{array}$ \\
\hline Sales Growth & $\begin{array}{c}0.056^{* * * *} \\
(3.47)\end{array}$ & $\begin{array}{l}-0.009 \\
(-0.46)\end{array}$ & $\begin{array}{l}0.020 \\
(0.74)\end{array}$ & $\begin{array}{c}-0.075^{* *} \\
(-2.41)\end{array}$ & $\begin{array}{l}0.021^{*} \\
(1.74)\end{array}$ & $\begin{array}{l}0.016^{*} \\
(1.66)\end{array}$ & $\begin{array}{c}0.054^{* * * *} \\
(4.33)\end{array}$ & $\begin{array}{c}0.074^{* * * *} \\
(3.44)\end{array}$ \\
\hline CapEx 2014 & $\begin{array}{c}-0.197^{* * * *} \\
(-3.05)\end{array}$ & $\begin{array}{l}-0.026 \\
(-0.27)\end{array}$ & $\begin{array}{l}-0.104 \\
(-0.85)\end{array}$ & $\begin{array}{l}-0.043 \\
(-0.30)\end{array}$ & $\begin{array}{l}0.938^{* * * *} \\
(11.40)\end{array}$ & $\begin{array}{c}1.021^{* * * *} \\
(7.71)\end{array}$ & $\begin{array}{c}0.972^{* * * *} \\
(7.66)\end{array}$ & $\begin{array}{c}1.098^{* * * *} \\
(8.20)\end{array}$ \\
\hline$R D$ & $\begin{array}{l}0.032 \\
(0.53)\end{array}$ & $\begin{array}{l}0.024 \\
(0.43)\end{array}$ & $\begin{array}{l}-0.023 \\
(-0.33)\end{array}$ & $\begin{array}{l}0.049 \\
(0.96)\end{array}$ & $\begin{array}{l}0.008 \\
(0.19)\end{array}$ & $\begin{array}{l}-0.025 \\
(-1.04)\end{array}$ & $\begin{array}{l}-0.029 \\
(-0.55)\end{array}$ & $\begin{array}{l}-0.041 \\
(-0.85)\end{array}$ \\
\hline$A C Q$ & $\begin{array}{l}-0.048^{*} \\
(-1.76)\end{array}$ & $\begin{array}{l}-0.023 \\
(-0.93)\end{array}$ & $\begin{array}{l}-0.017 \\
(-0.51)\end{array}$ & $\begin{array}{l}-0.010 \\
(-0.23)\end{array}$ & $\begin{array}{l}-0.025 \\
(-1.02)\end{array}$ & $\begin{array}{l}0.010 \\
(0.83)\end{array}$ & $\begin{array}{l}-0.023 \\
(-1.33)\end{array}$ & $\begin{array}{l}-0.033 \\
(-1.33)\end{array}$ \\
\hline Firm Age & $\begin{array}{l}-0.007 \\
(-1.40)\end{array}$ & $\begin{array}{l}-0.000 \\
(-0.02)\end{array}$ & $\begin{array}{l}-0.004 \\
(-0.60)\end{array}$ & $\begin{array}{l}0.019^{*} \\
(1.93)\end{array}$ & & & & \\
\hline$R E / B V$ & $\begin{array}{l}0.002 \\
(1.00)\end{array}$ & $\begin{array}{l}0.001 \\
(0.21)\end{array}$ & $\begin{array}{l}-0.004 \\
(-0.94)\end{array}$ & $\begin{array}{l}0.002 \\
(0.70)\end{array}$ & & & & \\
\hline Returns & $\begin{array}{l}-0.009 \\
(-1.44)\end{array}$ & $\begin{array}{l}-0.013^{*} \\
(-1.93)\end{array}$ & $\begin{array}{c}-0.028^{* * *} \\
(-3.16)\end{array}$ & $\begin{array}{l}-0.006 \\
(-0.55)\end{array}$ & & & & \\
\hline Options & $\begin{array}{c}-0.234^{* * * *} \\
(-4.58)\end{array}$ & $\begin{array}{c}-0.455^{* * * *} \\
(-5.20)\end{array}$ & $\begin{array}{c}-0.477^{* * * *} \\
(-3.62)\end{array}$ & $\begin{array}{c}-0.189^{* * *} \\
(-2.05)\end{array}$ & & & & \\
\hline St. Dev. Earnings & $\begin{array}{l}0.069 \\
(0.97)\end{array}$ & $\begin{array}{l}0.006 \\
(0.07)\end{array}$ & $\begin{array}{l}-0.037 \\
(-0.42)\end{array}$ & $\begin{array}{l}0.008 \\
(0.07)\end{array}$ & & & & \\
\hline Dividends Lag & $\begin{array}{l}0.422^{*} \\
(1.80)\end{array}$ & $\begin{array}{l}-0.087 \\
(-0.58)\end{array}$ & $\begin{array}{l}-0.161 \\
(-0.93)\end{array}$ & $\begin{array}{c}-0.516^{* * * *} \\
(-3.00)\end{array}$ & $\begin{array}{l}0.100 \\
(0.48)\end{array}$ & $\begin{array}{l}0.040 \\
(0.53)\end{array}$ & $\begin{array}{c}-0.412^{* *} \\
(-2.57)\end{array}$ & $\begin{array}{l}-0.143 \\
(-1.54)\end{array}$ \\
\hline Repurchase Lag & $\begin{array}{c}0.287^{* * * *} \\
(2.97)\end{array}$ & $\begin{array}{c}0.401^{* * * *} \\
(4.92)\end{array}$ & $\begin{array}{c}0.300^{* * * *} \\
(3.00)\end{array}$ & $\begin{array}{c}0.572^{* * * *} \\
(7.30)\end{array}$ & $\begin{array}{c}-0.071^{* * *} \\
(-2.11)\end{array}$ & $\begin{array}{l}-0.015 \\
(-0.63)\end{array}$ & $\begin{array}{l}-0.089^{*} \\
(-1.76)\end{array}$ & $\begin{array}{l}-0.015 \\
(-0.37)\end{array}$ \\
\hline Intercept & $\begin{array}{l}0.021 \\
(0.63)\end{array}$ & $\begin{array}{l}-0.029 \\
(-0.97)\end{array}$ & $\begin{array}{c}-0.083^{* *} \\
(-2.02)\end{array}$ & $\begin{array}{c}-0.351^{* * * *} \\
(-7.11)\end{array}$ & $\begin{array}{l}0.002 \\
(0.09)\end{array}$ & $\begin{array}{l}-0.005 \\
(-0.50)\end{array}$ & $\begin{array}{l}-0.032 \\
(-1.27)\end{array}$ & $\begin{array}{l}-0.014 \\
(-0.67)\end{array}$ \\
\hline $\begin{array}{l}N \\
\text { adj. } R^{2}\end{array}$ & 300 & 300 & 300 & 300 & $\begin{array}{c}300 \\
0.7070\end{array}$ & $\begin{array}{c}300 \\
0.7383\end{array}$ & $\begin{array}{c}300 \\
0.6585\end{array}$ & $\begin{array}{c}300 \\
0.6111\end{array}$ \\
\hline Log Likelihood & 1350.767 & 1470.973 & 1464.445 & 1396.396 & 714.192 & 849.811 & 702.679 & 628.841 \\
\hline
\end{tabular}

This table presents estimates from panel regressions on a sample of multinational firms explaining firm-level annual expenditure for the period $2015-2018$, excluding 2017. The dependent variable in Columns $1-4$ and $5-8$ is Repurchases and CapEx. Columns $1-4$ and $5-8$ are disaggregated by the quartile cutoffs of firm-level Z-Score. The 2014 fiscal year-end total assets is used as the scalar in the following variable definitions. Total Payout is the sum of Dividends and Repurchases. Dividends is total dividends paid scaled by total assets, set equal to zero when 
dividends are missing in Compustat. Repurchases are total repurchases scaled by total assets. A repurchase is identified as a positive value for purchases of common and preferred stock less any decrease in the redemption value of preferred stock in the prior year, or minus the decrease in preferred stock in the prior year, if the redemption value is missing. CapEx is capital expenditures scaled by total assets. Post is equal to one for fiscal years ending in 2018, zero otherwise. Foreign Cash is foreign cash at the end of fiscal year 2014 scaled by total assets. Domestic Cash is total cash minus foreign cash at the end of 2014, scaled by total assets. Book ETR is current federal tax expense scaled by pretax income minus special items, measured at the end of fiscal year 2014. Cash ETR is current taxes paid scaled by pretax income minus special items, measured at the end of fiscal year 2014. Loss is equal to 1 when income before extraordinary items is less than zero and equal to zero otherwise. Size is the natural logarithm of total assets at the end of fiscal year 2014. Earnings is income before extraordinary items scaled by total assets. Cash Flow is equal to operating cash flow scaled by total assets. Leverage is long term debt at the end of fiscal year 2014 scaled by total assets. MTB is market value of shares outstanding divided by the total book value. Sales Growth is total sales minus lagged sales, scaled by lagged sales. CapEx 2014 is total fiscal year 2014 capital expenditures scaled by total assets. $R D$ is equal to research and development expense scaled by total assets. $R D$ is equal to zero when missing in Compustat. $A C Q$ is equal to total expenditures on mergers and acquisitions scaled by total assets. $A C Q$ is equal to zero when missing in Compustat. Firm Age is the natural logarithm of the number of years the firm has been in Compustat. $R E / B V$ is the ratio of retained earnings to book value of common equity. Returns is monthly compounded stock return for the two years prior to period $t$. Options is the annual percentage change in total diluted shares outstanding of firm as if no repurchases were made during year $t$. St. Dev. Earnings is the standard deviation of earnings for the current and previous 4 years. Continuous variables are winsorized at the 1 and 99 percentiles. Two-digit SIC code industry fixed effects are included. ***, **, * represent significance at the $0.01,0.05,0.10$ twotailed significance levels. 
Table 6

Investment opportunities and the use of foreign cash following the TCJA

\begin{tabular}{|c|c|c|c|c|c|c|c|c|}
\hline & (1) & (2) & (3) & (4) & (5) & $(6)$ & $(7)$ & (8) \\
\hline & \multicolumn{4}{|c|}{ Repurchases } & \multicolumn{4}{|c|}{ CapEx } \\
\hline & $\begin{array}{c}\text { Under } \\
\text { Investment }\end{array}$ & $\begin{array}{c}\text { Marginal } \\
\text { Under } \\
\text { Investment }\end{array}$ & $\begin{array}{c}\text { Marginal } \\
\text { Over } \\
\text { Investment }\end{array}$ & $\begin{array}{c}\text { Over } \\
\text { Investment }\end{array}$ & $\begin{array}{c}\text { Under } \\
\text { Investment }\end{array}$ & $\begin{array}{c}\text { Marginal } \\
\text { Under } \\
\text { Investment }\end{array}$ & $\begin{array}{c}\text { Marginal } \\
\text { Over } \\
\text { Investment }\end{array}$ & $\begin{array}{c}\text { Over } \\
\text { Investment }\end{array}$ \\
\hline \multirow[t]{2}{*}{ Post } & -0.014 & -0.006 & $-0.022^{* *}$ & 0.001 & $0.005^{*}$ & 0.002 & 0.009 & 0.006 \\
\hline & $(-0.92)$ & $(-0.61)$ & $(-2.08)$ & $(0.08)$ & $(1.79)$ & $(0.55)$ & $(1.65)$ & $(1.45)$ \\
\hline \multirow[t]{2}{*}{ Foreign Cash } & 0.042 & 0.061 & 0.013 & -0.015 & 0.001 & $-0.031^{*}$ & -0.004 & 0.036 \\
\hline & $(0.64)$ & $(1.54)$ & $(0.28)$ & $(-0.24)$ & $(0.10)$ & $(-1.93)$ & $(-0.23)$ & $(1.47)$ \\
\hline \multirow[t]{2}{*}{ Foreign Cash $\times$ Post } & $0.211^{*}$ & $0.263^{* *}$ & $0.334^{* * *}$ & 0.095 & -0.012 & 0.018 & -0.027 & -0.031 \\
\hline & (1.89) & $(2.15)$ & $(2.07)$ & $(0.65)$ & $(-0.72)$ & $(0.74)$ & $(-0.98)$ & $(-0.70)$ \\
\hline \multirow[t]{2}{*}{ Domestic Cash } & $0.105^{* *}$ & $0.068^{*}$ & 0.054 & 0.022 & 0.014 & 0.006 & 0.018 & $0.031^{* *}$ \\
\hline & $(2.47)$ & $(1.93)$ & $(1.18)$ & $(0.53)$ & (1.08) & $(0.30)$ & $(0.58)$ & (2.17) \\
\hline \multirow[t]{2}{*}{ Book ETR } & $0.075^{* * * *}$ & -0.014 & -0.025 & -0.005 & 0.001 & -0.010 & 0.011 & -0.001 \\
\hline & $(3.05)$ & $(-0.72)$ & $(-1.39)$ & $(-0.34)$ & $(0.21)$ & $(-1.11)$ & (1.56) & $(-0.14)$ \\
\hline \multirow[t]{2}{*}{ Cash ETR } & -0.031 & 0.024 & -0.024 & 0.021 & 0.006 & 0.011 & $-0.012^{*}$ & -0.001 \\
\hline & $(-1.08)$ & $(1.42)$ & $(-1.35)$ & (1.18) & (1.05) & (1.41) & $(-1.96)$ & $(-0.09)$ \\
\hline \multirow[t]{2}{*}{ Loss } & -0.024 & -0.012 & 0.001 & -0.002 & -0.005 & -0.004 & -0.007 & -0.005 \\
\hline & $(-1.43)$ & $(-1.09)$ & $(0.06)$ & $(-0.26)$ & $(-1.48)$ & $(-0.95)$ & $(-1.12)$ & $(-1.00)$ \\
\hline \multirow[t]{2}{*}{ Size } & 0.004 & 0.002 & 0.006 & 0.003 & -0.001 & 0.001 & -0.000 & 0.001 \\
\hline & (1.16) & $(0.59)$ & (1.57) & (1.13) & $(-0.79)$ & $(0.61)$ & $(-0.05)$ & $(0.52)$ \\
\hline \multirow[t]{2}{*}{ Earnings } & -0.027 & 0.074 & 0.121 & 0.025 & -0.005 & 0.041 & 0.084 & -0.029 \\
\hline & $(-0.40)$ & (1.06) & (1.16) & $(0.49)$ & $(-0.51)$ & (1.07) & (1.48) & $(-0.82)$ \\
\hline \multirow[t]{2}{*}{ Cash Flow } & $0.306^{* * * *}$ & 0.036 & 0.096 & $0.155^{* * *}$ & 0.007 & 0.004 & -0.058 & 0.022 \\
\hline & $(3.80)$ & $(0.55)$ & $(1.50)$ & $(2.22)$ & $(0.31)$ & $(0.11)$ & $(-1.22)$ & $(0.37)$ \\
\hline \multirow[t]{2}{*}{ Leverage } & 0.013 & 0.016 & -0.030 & $-0.050^{* *}$ & 0.000 & -0.009 & 0.002 & -0.002 \\
\hline & $(0.39)$ & $(0.55)$ & $(-0.99)$ & $(-2.05)$ & $(0.07)$ & $(-0.92)$ & $(0.15)$ & $(-0.18)$ \\
\hline \multirow[t]{2}{*}{$M T B$} & 0.001 & -0.001 & -0.000 & -0.000 & 0.000 & -0.000 & $0.001^{*}$ & $0.000^{*}$ \\
\hline & (1.27) & $(-0.75)$ & $(-1.46)$ & $(-0.45)$ & $(1.22)$ & $(-0.84)$ & (1.81) & (1.97) \\
\hline \multirow[t]{2}{*}{ Sales Growth } & -0.001 & -0.011 & -0.010 & $-0.037^{*}$ & $0.032^{* * *}$ & 0.006 & -0.014 & $0.040^{* * * *}$ \\
\hline & $(-0.02)$ & $(-0.61)$ & $(-0.48)$ & $(-1.83)$ & $(5.51)$ & $(0.77)$ & $(-1.05)$ & $(2.87)$ \\
\hline \multirow[t]{2}{*}{ CapEx 2014} & -0.249 & -0.175 & -0.173 & -0.039 & $0.906^{* * * *}$ & $0.649^{* * * *}$ & $0.940^{* * * *}$ & $0.968^{* * * *}$ \\
\hline & $(-0.59)$ & $(-1.20)$ & $(-1.11)$ & $(-0.35)$ & $(10.36)$ & (6.94) & (10.84) & (12.87) \\
\hline \multirow[t]{2}{*}{$R D$} & 0.048 & -0.013 & 0.029 & 0.048 & 0.006 & 0.063 & -0.010 & -0.021 \\
\hline & $(0.35)$ & $(-0.10)$ & $(0.28)$ & $(0.77)$ & $(0.26)$ & (1.13) & $(-0.26)$ & $(-1.04)$ \\
\hline \multirow[t]{2}{*}{$A C Q$} & 0.056 & -0.021 & $-0.044^{*}$ & -0.025 & 0.003 & 0.003 & 0.017 & -0.001 \\
\hline & $(1.15)$ & $(-1.23)$ & $(-1.65)$ & $(-1.34)$ & $(0.34)$ & $(0.51)$ & $(1.61)$ & $(-0.09)$ \\
\hline Firm Age & 0.005 & -0.010 & -0.013 & 0.008 & & & & \\
\hline & $(0.48)$ & $(-1.12)$ & $(-0.96)$ & $(0.94)$ & & & & \\
\hline$R E / B V$ & 0.000 & $0.008^{* * *}$ & -0.001 & -0.000 & & & & \\
\hline & $(0.33)$ & $(2.74)$ & $(-0.91)$ & $(-0.06)$ & & & & \\
\hline Returns & $-0.041^{* * *}$ & $-0.012^{*}$ & -0.017 & $-0.017^{* *}$ & & & & \\
\hline & $(-2.74)$ & $(-1.94)$ & $(-0.94)$ & $(-2.16)$ & & & & \\
\hline Options & -0.036 & -0.043 & -0.045 & 0.021 & & & & \\
\hline & $(-0.99)$ & $(-0.82)$ & $(-1.65)$ & $(0.57)$ & & & & \\
\hline St. Dev. Earnings & 0.177 & 0.075 & -0.042 & -0.135 & & & & \\
\hline & $(1.55)$ & $(0.94)$ & $(-0.37)$ & $(-1.53)$ & & & & \\
\hline Dividends Lag & -0.239 & 0.092 & $-0.468^{* *}$ & -0.250 & 0.032 & $-0.231^{*}$ & -0.071 & -0.101 \\
\hline & $(-1.41)$ & $(0.56)$ & $(-2.13)$ & $(-0.93)$ & $(0.78)$ & $(-1.80)$ & $(-0.62)$ & $(-1.29)$ \\
\hline Repurchase Lag & $0.480^{* * * *}$ & $0.486^{* * *}$ & $0.425^{* * *}$ & $0.784^{* * *}$ & 0.011 & -0.008 & 0.021 & $-0.056^{*}$ \\
\hline & $(4.07)$ & $(4.88)$ & $(5.69)$ & (6.10) & $(0.70)$ & $(-0.21)$ & $(0.78)$ & $(-1.68)$ \\
\hline Intercept & -0.074 & -0.008 & 0.045 & -0.050 & 0.002 & 0.018 & -0.002 & -0.012 \\
\hline & $(-0.98)$ & $(-0.18)$ & $(0.74)$ & $(-1.06)$ & $(0.27)$ & $(1.28)$ & $(-0.08)$ & $(-0.60)$ \\
\hline$N$ & 234 & 234 & 234 & 234 & 234 & 234 & 234 & 234 \\
\hline adj. $R^{2}$ & & & & & 0.7814 & 0.6647 & 0.6740 & 0.7860 \\
\hline Log Likelihood & 1279.067 & 1312.525 & 1306.875 & 1268.342 & 717.402 & 656.377 & 565.695 & 582.033 \\
\hline
\end{tabular}

This table presents estimates from panel regressions on a sample of multinational firms explaining firm-level annual expenditure for the period $2015-2018$, excluding 2017. The dependent variable in Columns $1-4$ and $5-8$ is Repurchases and CapEx. Columns $1-4$ and 5-8 are disaggregated by the quartile cutoffs of abnormal investment from Biddle et al. (2009). The 2014 fiscal year-end total assets is used as the scalar in the following variable 
definitions. Total Payout is the sum of Dividends and Repurchases. Dividends is total dividends paid scaled by total assets, set equal to zero when dividends are missing in Compustat. Repurchases are total repurchases scaled by total assets. A repurchase is identified as a positive value for purchases of common and preferred stock less any decrease in the redemption value of preferred stock in the prior year, or minus the decrease in preferred stock in the prior year, if the redemption value is missing. CapEx is capital expenditures scaled by total assets. Post is equal to one for fiscal years ending in 2018, zero otherwise. Foreign Cash is foreign cash at the end of fiscal year 2014 scaled by total assets. Domestic Cash is total cash minus foreign cash at the end of 2014, scaled by total assets. Book ETR is current federal tax expense scaled by pretax income minus special items, measured at the end of fiscal year 2014. Cash ETR is current taxes paid scaled by pretax income minus special items, measured at the end of fiscal year 2014. Loss is equal to 1 when income before extraordinary items is less than zero and equal to zero otherwise. Size is the natural logarithm of total assets at the end of fiscal year 2014. Earnings is income before extraordinary items scaled by total assets. Cash Flow is equal to operating cash flow scaled by total assets. Leverage is long term debt at the end of fiscal year 2014 scaled by total assets. MTB is market value of shares outstanding divided by the total book value. Sales Growth is total sales minus lagged sales, scaled by lagged sales. CapEx 2014 is total fiscal year 2014 capital expenditures scaled by total assets. $R D$ is equal to research and development expense scaled by total assets. $R D$ is equal to zero when missing in Compustat. $A C Q$ is equal to total expenditures on mergers and acquisitions scaled by total assets. $A C Q$ is equal to zero when missing in Compustat. Firm Age is the natural logarithm of the number of years the firm has been in Compustat. $R E / B V$ is the ratio of retained earnings to book value of common equity. Returns is monthly compounded stock return for the two years prior to period $t$. Options is the annual percentage change in total diluted shares outstanding of firm as if no repurchases were made during year t. St. Dev. Earnings is the standard deviation of earnings for the current and previous 4 years. Continuous variables are winsorized at the 1 and 99 percentiles. Two-digit SIC code industry fixed effects are included. ***, **, * represent significance at the $0.01,0.05,0.10$ two-tailed significance levels. 


\section{Table 7}

Domestic and foreign capital expenditure

\begin{tabular}{|c|c|c|}
\hline & $\begin{array}{c}(1) \\
\text { Domestic CapEx } \\
\text { Marginal } \\
\text { Weak Health } \\
\end{array}$ & $\begin{array}{c}(2) \\
\text { Foreign CapEx } \\
\text { Marginal } \\
\text { Weak Health }\end{array}$ \\
\hline Post & $\begin{array}{c}-0.020^{* * *} \\
(-3.35)\end{array}$ & $\begin{array}{l}-0.001 \\
(-0.12)\end{array}$ \\
\hline Foreign Cash & $\begin{array}{l}0.045 \\
(0.86)\end{array}$ & $\begin{array}{l}0.042 \\
(0.78)\end{array}$ \\
\hline Foreign Cash $\times$ Post & $\begin{array}{l}\mathbf{0 . 1 1 1}^{* *} \\
(2.02)\end{array}$ & $\begin{array}{l}0.026 \\
(0.45)\end{array}$ \\
\hline Book ETR & $\begin{array}{l}0.002 \\
(0.11)\end{array}$ & $\begin{array}{l}-0.050^{*} \\
(-1.83)\end{array}$ \\
\hline Cash ETR & $\begin{array}{l}-0.049^{*} \\
(-1.92)\end{array}$ & $\begin{array}{l}0.037 \\
(1.31)\end{array}$ \\
\hline Loss & $\begin{array}{l}0.035^{* *} \\
(2.30)\end{array}$ & $\begin{array}{l}-0.037^{* * *} \\
(-2.19)\end{array}$ \\
\hline Size & $\begin{array}{l}0.004^{*} \\
(1.77)\end{array}$ & $\begin{array}{l}0.004 \\
(1.32)\end{array}$ \\
\hline Foreign Earnings & $\begin{array}{l}-0.055 \\
(-0.50)\end{array}$ & $\begin{array}{l}-0.195 \\
(-1.27)\end{array}$ \\
\hline Domestic Earnings & $\begin{array}{l}0.285^{* *} \\
(2.54)\end{array}$ & $\begin{array}{l}-0.226 \\
(-1.42)\end{array}$ \\
\hline Cash Flow & $\begin{array}{l}-0.104 \\
(-1.37)\end{array}$ & $\begin{array}{l}0.168^{* *} \\
(2.12)\end{array}$ \\
\hline Leverage & $\begin{array}{l}0.005 \\
(0.22)\end{array}$ & $\begin{array}{l}-0.030 \\
(-1.36)\end{array}$ \\
\hline$M T B$ & $\begin{array}{l}-0.000^{*} \\
(-1.87)\end{array}$ & $\begin{array}{l}0.000^{*} \\
(1.84)\end{array}$ \\
\hline Sales Growth & $\begin{array}{l}0.076^{* * * *} \\
(2.84)\end{array}$ & $\begin{array}{l}-0.006 \\
(-0.29)\end{array}$ \\
\hline CapEx 2014 & $\begin{array}{l}0.671^{* * * *} \\
(3.22)\end{array}$ & $\begin{array}{l}0.636^{* * * *} \\
(2.67)\end{array}$ \\
\hline$R D$ & $\begin{array}{l}-0.221^{*} \\
(-1.77)\end{array}$ & $\begin{array}{l}0.061 \\
(0.48)\end{array}$ \\
\hline$A C Q$ & $\begin{array}{c}0.147^{* * * *} \\
(3.68)\end{array}$ & $\begin{array}{l}0.068^{* * *} \\
(2.01)\end{array}$ \\
\hline Depr & $\begin{array}{l}0.319 \\
(1.07)\end{array}$ & $\begin{array}{l}-0.521^{*} \\
(-1.72)\end{array}$ \\
\hline Intercept & $\begin{array}{l}-0.045^{*} \\
(-1.71) \\
\end{array}$ & $\begin{array}{l}-0.026 \\
(-0.79) \\
\end{array}$ \\
\hline $\begin{array}{l}N \\
\text { adj. } R^{2}\end{array}$ & $\begin{array}{c}164 \\
0.5697\end{array}$ & $\begin{array}{c}164 \\
0.1485 \\
\end{array}$ \\
\hline
\end{tabular}

This table presents estimates from panel regressions on a sample of multinational firms explaining firm-level domestic and foreign capital expenditures for the period 2016 and 2018. The sample is constrained to marginally weak financial health firms which are firms where the Z-Score is between 2.131 and 3.466. The dependent variable in column 1 and 2 is domestic and foreign capital expenditures, respectively. The 2014 fiscal year-end total assets is used as the scalar in the following variable definitions. Total Payout is the sum of Dividends and Repurchases. Dividends is total dividends paid scaled by total assets, set equal to zero when dividends are missing in Compustat. Repurchases are total repurchases scaled by total assets. A repurchase is identified as a positive value for purchases of common and preferred stock less any decrease in the redemption value of preferred stock in the prior year, or 
minus the decrease in preferred stock in the prior year, if the redemption value is missing. CapEx is capital expenditures scaled by total assets. Post is equal to one for fiscal years ending in 2018, zero otherwise. Foreign Cash is foreign cash at the end of fiscal year 2014 scaled by total assets. Domestic Cash is total cash minus foreign cash at the end of 2014, scaled by total assets. Book ETR is current federal tax expense scaled by pretax income minus special items, measured at the end of fiscal year 2014. Cash ETR is current taxes paid scaled by pretax income minus special items, measured at the end of fiscal year 2014. Loss is equal to 1 when income before extraordinary items is less than zero and equal to zero otherwise. Size is the natural logarithm of total assets at the end of fiscal year 2014. Earnings is income before extraordinary items scaled by total assets. Cash Flow is equal to operating cash flow scaled by total assets. Leverage is long term debt at the end of fiscal year 2014 scaled by total assets. MTB is market value of shares outstanding divided by the total book value. Sales Growth is total sales minus lagged sales, scaled by lagged sales. CapEx 2014 is total fiscal year 2014 capital expenditures scaled by total assets. $R D$ is equal to research and development expense scaled by total assets. $R D$ is equal to zero when missing in Compustat. $A C Q$ is equal to total expenditures on mergers and acquisitions scaled by total assets. $A C Q$ is equal to zero when missing in Compustat. Firm Age is the natural logarithm of the number of years the firm has been in Compustat. $R E / B V$ is the ratio of retained earnings to book value of common equity. Returns is monthly compounded stock return for the two years prior to period $t$. Options is the annual percentage change in total diluted shares outstanding of firm as if no repurchases were made during year $t$. St. Dev. Earnings is the standard deviation of earnings for the current and previous 4 years. Continuous variables are winsorized at the 1 and 99 percentiles. Two-digit SIC code industry fixed effects are included. ***, **, * represent significance at the $0.01,0.05,0.10$ twotailed significance levels. 


\section{Table 8}

Difference-in-differences analysis

Panel A: Full Sample

\begin{tabular}{|c|c|c|c|c|}
\hline & $\begin{array}{c}\text { (1) } \\
\text { Total } \\
\text { Payout }\end{array}$ & $\begin{array}{c}\text { (2) } \\
\text { Repurchases }\end{array}$ & $\begin{array}{c}\text { (3) } \\
\text { CapEx }\end{array}$ & $\begin{array}{c}\text { (4) } \\
\text { Domestic } \\
\text { CapEx }\end{array}$ \\
\hline Post & $\begin{array}{l}0.012 \\
(0.79)\end{array}$ & $\begin{array}{l}0.006 \\
(0.40)\end{array}$ & $\begin{array}{l}-0.007 \\
(-0.68)\end{array}$ & $\begin{array}{c}-0.005^{* *} \\
(-2.37)\end{array}$ \\
\hline$M N C$ & $\begin{array}{l}-0.002 \\
(-0.85)\end{array}$ & $\begin{array}{l}0.001 \\
(0.51)\end{array}$ & $\begin{array}{c}-0.006^{* * * *} \\
(-3.22)\end{array}$ & $\begin{array}{l}0.005^{*} \\
(1.92)\end{array}$ \\
\hline$M N C \times$ Post & $\begin{array}{c}\mathbf{0 . 0 0 8}^{* * *} \\
(2.07)\end{array}$ & $\begin{array}{l}\mathbf{0 . 0 0 6}^{*} \\
(1.74)\end{array}$ & $\begin{array}{l}-0.004 \\
(-0.87)\end{array}$ & $\begin{array}{c}\mathbf{0 . 0 0 6}^{* *} \\
(2.05)\end{array}$ \\
\hline Book ETR & $\begin{array}{l}0.003 \\
(0.59)\end{array}$ & $\begin{array}{l}0.002 \\
(0.32)\end{array}$ & $\begin{array}{l}-0.005 \\
(-1.15)\end{array}$ & $\begin{array}{l}-0.001 \\
(-0.24)\end{array}$ \\
\hline Cash ETR & $\begin{array}{l}0.006 \\
(1.28)\end{array}$ & $\begin{array}{l}0.005 \\
(1.05)\end{array}$ & $\begin{array}{l}-0.003 \\
(-0.77)\end{array}$ & $\begin{array}{l}-0.006 \\
(-1.36)\end{array}$ \\
\hline Loss & $\begin{array}{l}-0.003 \\
(-0.95)\end{array}$ & $\begin{array}{l}-0.004 \\
(-1.63)\end{array}$ & $\begin{array}{l}-0.004 \\
(-1.56)\end{array}$ & $\begin{array}{c}-0.008^{* * * *} \\
(-3.92)\end{array}$ \\
\hline Size & $\begin{array}{l}0.002^{* *} \\
(2.42)\end{array}$ & $\begin{array}{c}0.003^{* * *} \\
(4.75)\end{array}$ & $\begin{array}{l}0.001 \\
(1.47)\end{array}$ & $\begin{array}{l}0.001 \\
(1.31)\end{array}$ \\
\hline Earnings & $\begin{array}{l}-0.002 \\
(-0.25)\end{array}$ & $\begin{array}{l}-0.005 \\
(-0.82)\end{array}$ & $\begin{array}{l}-0.001 \\
(-0.50)\end{array}$ & $\begin{array}{l}0.006^{*} \\
(1.67)\end{array}$ \\
\hline Cash Flow & $\begin{array}{c}0.107^{* * * *} \\
(7.03)\end{array}$ & $\begin{array}{c}0.079^{* * * *} \\
(5.82)\end{array}$ & $\begin{array}{c}0.026^{* * *} \\
(2.23)\end{array}$ & $\begin{array}{l}-0.009^{*} \\
(-1.91)\end{array}$ \\
\hline Leverage & $\begin{array}{c}-0.026^{* * * *} \\
(-4.40)\end{array}$ & $\begin{array}{c}-0.019^{* * * *} \\
(-3.47)\end{array}$ & $\begin{array}{c}-0.017^{* * * *} \\
(-2.89)\end{array}$ & $\begin{array}{l}-0.001 \\
(-0.24)\end{array}$ \\
\hline$M T B$ & $\begin{array}{c}0.001^{* * * *} \\
(3.80)\end{array}$ & $\begin{array}{c}0.001^{* * * *} \\
(2.91)\end{array}$ & $\begin{array}{l}0.000 \\
(1.11)\end{array}$ & $\begin{array}{l}-0.006 \\
(-1.36)\end{array}$ \\
\hline Sales Growth & $\begin{array}{l}-0.002 \\
(-0.30)\end{array}$ & $\begin{array}{l}-0.003 \\
(-0.52)\end{array}$ & $\begin{array}{c}0.046^{* * * *} \\
(5.62)\end{array}$ & $\begin{array}{c}-0.008^{* * * *} \\
(-3.92)\end{array}$ \\
\hline CapEx 2014 & $\begin{array}{c}-0.078^{* * * *} \\
(-3.30)\end{array}$ & $\begin{array}{c}-0.070^{* * * *} \\
(-3.11)\end{array}$ & $\begin{array}{c}0.963^{* * * *} \\
(21.67)\end{array}$ & $\begin{array}{l}0.001 \\
(1.31)\end{array}$ \\
\hline$R D$ & $\begin{array}{l}-0.008 \\
(-0.45)\end{array}$ & $\begin{array}{l}0.002 \\
(0.12)\end{array}$ & $\begin{array}{l}-0.009 \\
(-0.84)\end{array}$ & $\begin{array}{l}0.006^{*} \\
(1.67)\end{array}$ \\
\hline$A C Q$ & $\begin{array}{c}-0.032^{* *} \\
(-2.11)\end{array}$ & $\begin{array}{c}-0.042^{* * * *} \\
(-2.93)\end{array}$ & $\begin{array}{l}-0.003 \\
(-0.29)\end{array}$ & $\begin{array}{c}0.071^{* * * *} \\
(4.45)\end{array}$ \\
\hline Firm Age & $\begin{array}{l}0.002 \\
(0.89)\end{array}$ & $\begin{array}{l}-0.002 \\
(-1.07)\end{array}$ & & \\
\hline$R E / B V$ & $\begin{array}{c}0.002^{* * * *} \\
(3.06)\end{array}$ & $\begin{array}{c}0.001^{* *} \\
(2.42)\end{array}$ & & \\
\hline Returns & $\begin{array}{c}-0.007^{* *} \\
(-2.53)\end{array}$ & $\begin{array}{c}-0.008^{* * * *} \\
(-2.98)\end{array}$ & & \\
\hline Options & $\begin{array}{l}-0.034^{*} \\
(-1.94)\end{array}$ & $\begin{array}{c}-0.052^{* * * *} \\
(-3.16)\end{array}$ & & \\
\hline St. Dev. Earnings & $\begin{array}{l}-0.009 \\
(-0.38)\end{array}$ & $\begin{array}{l}-0.011 \\
(-0.49)\end{array}$ & & \\
\hline Dividends Lag & $\begin{array}{l}1.187^{* * *} \\
(16.40)\end{array}$ & $\begin{array}{l}-0.018 \\
(-0.27)\end{array}$ & $\begin{array}{c}-0.108^{* * *} \\
(-2.18)\end{array}$ & $\begin{array}{l}-0.007 \\
(-0.14)\end{array}$ \\
\hline Repurchase Lag & $\begin{array}{c}0.698^{* * * *} \\
(18.74)\end{array}$ & $\begin{array}{l}0.724^{* * *} \\
(22.04)\end{array}$ & $\begin{array}{l}0.017 \\
(0.89)\end{array}$ & $\begin{array}{l}-0.008^{*} \\
(-1.86)\end{array}$ \\
\hline Intercept & $\begin{array}{l}-0.045^{*} \\
(-1.76)\end{array}$ & $\begin{array}{l}-0.034 \\
(-1.47) \\
\end{array}$ & $\begin{array}{l}-0.011 \\
(-0.83) \\
\end{array}$ & $\begin{array}{c}0.015^{* * * *} \\
(3.42) \\
\end{array}$ \\
\hline $\begin{array}{l}N \\
\text { adj. } R^{2} \\
\text { Log Likelihood }\end{array}$ & 4470.413 & 3955.637 & $\begin{array}{c}4,032 \\
0.5302 \\
5909.569\end{array}$ & $\begin{array}{c}2,804 \\
0.0466\end{array}$ \\
\hline
\end{tabular}


Panel B: Financial Health Cross-Section

\begin{tabular}{|c|c|c|c|c|}
\hline & $\begin{array}{c}\text { (1) } \\
\text { Repurchases } \\
\text { Weak Health }\end{array}$ & $\begin{array}{c}\text { (2) } \\
\text { Repurchases } \\
\text { Strong Health }\end{array}$ & $\begin{array}{c}\text { (3) } \\
\text { Domestic CapEx } \\
\text { Weak Health }\end{array}$ & $\begin{array}{c}\text { (4) } \\
\text { Domestic CapEx } \\
\text { Strong Health }\end{array}$ \\
\hline \multirow[t]{2}{*}{ Post } & 0.021 & -0.016 & -0.004 & $-0.005^{* *}$ \\
\hline & (1.28) & $(-0.66)$ & $(-1.43)$ & $(-2.04)$ \\
\hline \multirow[t]{2}{*}{$M N C$} & -0.003 & $0.006^{*}$ & $-0.007^{*}$ & $0.016^{* * *}$ \\
\hline & $(-1.18)$ & $(1.71)$ & $(-1.90)$ & $(5.51)$ \\
\hline \multirow[t]{2}{*}{$M N C \times P o s t$} & $0.008^{* * *}$ & 0.003 & $0.012^{* * * *}$ & 0.002 \\
\hline & $(2.11)$ & $(0.49)$ & $(2.66)$ & $(\mathbf{0 . 7 0})$ \\
\hline \multirow[t]{2}{*}{ Book ETR } & -0.003 & 0.008 & 0.001 & -0.006 \\
\hline & $(-0.64)$ & $(0.83)$ & $(0.15)$ & $(-1.15)$ \\
\hline \multirow[t]{2}{*}{ Cash ETR } & 0.003 & 0.009 & -0.003 & -0.006 \\
\hline & $(0.60)$ & (1.07) & $(-0.59)$ & $(-0.96)$ \\
\hline \multirow[t]{2}{*}{ Loss } & -0.003 & -0.004 & $-0.008^{* *}$ & $-0.008^{* *}$ \\
\hline & $(-1.27)$ & $(-0.77)$ & $(-2.52)$ & $(-2.41)$ \\
\hline \multirow[t]{2}{*}{ Size } & $0.003^{* * *}$ & $0.003^{* * *}$ & $0.001^{* *}$ & -0.001 \\
\hline & $(4.12)$ & $(2.88)$ & $(2.12)$ & $(-1.28)$ \\
\hline \multirow[t]{2}{*}{ Earnings } & -0.006 & 0.001 & 0.004 & 0.008 \\
\hline & $(-1.11)$ & $(0.09)$ & (1.01) & $(0.84)$ \\
\hline \multirow[t]{2}{*}{ Cash Flow } & $0.057^{* * *}$ & $0.091^{* * * *}$ & -0.007 & $-0.015^{*}$ \\
\hline & $(3.05)$ & $(4.46)$ & $(-1.22)$ & $(-1.78)$ \\
\hline \multirow[t]{2}{*}{ Leverage } & $-0.017^{* * *}$ & $-0.023^{* *}$ & 0.006 & 0.007 \\
\hline & $(-2.63)$ & $(-2.42)$ & (1.60) & (1.60) \\
\hline \multirow[t]{2}{*}{$M T B$} & 0.001 & $0.001^{* * *}$ & 0.000 & 0.000 \\
\hline & $(1.23)$ & $(2.72)$ & $(0.05)$ & $(0.93)$ \\
\hline \multirow[t]{2}{*}{ Sales Growth } & 0.000 & -0.007 & 0.003 & $0.007^{* *}$ \\
\hline & $(0.01)$ & $(-0.72)$ & (1.02) & $(2.48)$ \\
\hline \multirow[t]{2}{*}{ CapEx 2014} & $-0.050^{*}$ & $-0.094^{* * *}$ & 0.011 & 0.044 \\
\hline & $(-1.88)$ & $(-2.59)$ & $(0.32)$ & (1.14) \\
\hline \multirow[t]{2}{*}{$R D$} & 0.009 & 0.006 & $0.018^{* *}$ & -0.008 \\
\hline & $(0.42)$ & $(0.28)$ & $(2.08)$ & $(-0.71)$ \\
\hline \multirow[t]{2}{*}{$A C Q$} & -0.028 & $-0.060^{* * *}$ & $0.084^{* * *}$ & $0.065^{* * *}$ \\
\hline & $(-1.50)$ & $(-2.86)$ & $(2.78)$ & $(3.50)$ \\
\hline \multirow[t]{2}{*}{ Firm Age } & -0.002 & -0.003 & & \\
\hline & $(-0.77)$ & $(-0.87)$ & & \\
\hline \multirow[t]{2}{*}{$R E / B V$} & 0.001 & $0.002^{*}$ & & \\
\hline & (1.39) & $(1.92)$ & & \\
\hline \multirow[t]{2}{*}{ Returns } & -0.004 & $-0.012^{* *}$ & & \\
\hline & $(-1.49)$ & $(-2.52)$ & & \\
\hline \multirow[t]{2}{*}{ Options } & $-0.040^{* *}$ & $-0.081^{* * *}$ & & \\
\hline & $(-2.04)$ & $(-2.90)$ & & \\
\hline \multirow[t]{2}{*}{ St. Dev. Earnings } & -0.017 & -0.003 & & \\
\hline & $(-0.70)$ & $(-0.09)$ & & \\
\hline \multirow[t]{2}{*}{ Dividends Lag } & 0.023 & -0.055 & 0.049 & -0.014 \\
\hline & $(0.21)$ & $(-0.61)$ & $(0.43)$ & $(-0.25)$ \\
\hline \multirow[t]{2}{*}{ Repurchase Lag } & $0.724^{* * *}$ & $0.699^{* * *}$ & -0.002 & $-0.012^{* *}$ \\
\hline & $(12.43)$ & $(16.50)$ & $(-0.16)$ & $(-2.42)$ \\
\hline Intercept & 0.001 & -0.040 & 0.011 & $0.024^{* * * *}$ \\
\hline & $(0.09)$ & $(-1.54)$ & $(1.41)$ & $(4.36)$ \\
\hline$N$ & 2,016 & 2,016 & 1,401 & 1,403 \\
\hline adj. $R^{2}$ & & & 0.0327 & 0.0794 \\
\hline Log Likelihood & 2033.570 & 2011.036 & & \\
\hline
\end{tabular}


This table presents estimates from difference-in-differences regressions a combined sample of domestic and multinational firms explaining firm-level repurchases and capital expenditures. Panel A uses the full sample and Panel B disaggregates the sample on the Z-Score median. The 2014 fiscal year-end total assets is used as the scalar in the following variable definitions. Total Payout is the sum of Dividends and Repurchases. Dividends is total dividends paid scaled by total assets, set equal to zero when dividends are missing in Compustat. Repurchases are total repurchases scaled by total assets. A repurchase is identified as a positive value for purchases of common and preferred stock less any decrease in the redemption value of preferred stock in the prior year, or minus the decrease in preferred stock in the prior year, if the redemption value is missing. CapEx is capital expenditures scaled by total assets. Post is equal to one for fiscal years ending in 2018, zero otherwise. MNC is equal to 1 if the firm reports nonmissing pretax foreign income from the period 2011 - 2013. Book ETR is current federal tax expense scaled by pretax income minus special items, measured at the end of fiscal year 2014. Cash ETR is current taxes paid scaled by pretax income minus special items, measured at the end of fiscal year 2014. Loss is equal to 1 when income before extraordinary items is less than zero and equal to zero otherwise. Size is the natural logarithm of total assets at the end of fiscal year 2014. Earnings is income before extraordinary items scaled by total assets. Cash Flow is equal to operating cash flow scaled by total assets. Leverage is long term debt at the end of fiscal year 2014 scaled by total assets. MTB is market value of shares outstanding divided by the total book value. Sales Growth is total sales minus lagged sales, scaled by lagged sales. CapEx 2014 is total fiscal year 2014 capital expenditures scaled by total assets. $R D$ is equal to research and development expense scaled by total assets. $R D$ is equal to zero when missing in Compustat. $A C Q$ is equal to total expenditures on mergers and acquisitions scaled by total assets. $A C Q$ is equal to zero when missing in Compustat. Firm Age is the natural logarithm of the number of years the firm has been in Compustat. $R E / B V$ is the ratio of retained earnings to book value of common equity. Returns is monthly compounded stock return for the two years prior to period $t$. Options is the annual percentage change in total diluted shares outstanding of firm as if no repurchases were made during year $t$. St. Dev. Earnings is the standard deviation of earnings for the current and previous 4 years. Continuous variables are winsorized at the 1 and 99 percentiles. Two-digit SIC code industry fixed effects are included. $* * *, * *, *$ represent significance at the $0.01,0.05,0.10$ twotailed significance levels. 